\title{
Natural Law and the Chair of Ethics in the University of Naples, 1703-1769
}

\author{
Felix Waldmann* \\ Christ's College, Cambridge \\ *Corresponding author. E-mail: few23@cam.ac.uk
}

\begin{abstract}
This articles focuses on a significant change to the curriculum in "ethics" (moral philosophy) in the University of Naples, superintended by Celestino Galiani, the rector of the university (1732-53), and Antonio Genovesi, Galiani's protégé and the university's professor of ethics (1746-54). The article contends that Galiani's and Genovesi's sympathies lay with the form of "modern natural law" pioneered by Hugo Grotius and his followers in Northern Europe. The transformation of curricular ethics in Protestant contexts had stemmed from an anxiety about its relevance in the face of moral skepticism. The article shows how this anxiety affected a Catholic context, and it responds to John Robertson's contention that Giambattista Vico's use of "sacred history" in his Scienza nuova (1725, revised 1730,1744) typified a search among Catholics for an alternative to "scholastic natural law," when the latter was found insufficiently to explain the sources of human sociability.
\end{abstract}

In August 1746, Antonio Genovesi was appointed to a professorship of moral philosophy or "ethics" in the University of Naples. The appointment marked a second attempt by Celestino Galiani, the university's rector or cappellano maggiore, to secure Genovesi a permanent chair (cattedra), after his failed attempt to install Genovesi in the cattedra of logic and metaphysics in March $1744 .{ }^{1}$ Until Genovesi's appointment in May 1754 to a professorship of commerce, he would hold the cattedra di etica only in anticipation of a contest or concorso, in which any aspirant could vie for the post. In 1754, after "more than thirty candidates" had applied to succeed Genovesi, Gaetano Maria Capece was awarded the cattedra. ${ }^{2}$ A letter of 1765 from Genovesi to Capece would later appear in a collection of Capece's Opuscula (1785-90), in which Capece is described, on its title page, as a professor of "ethics, and natural law." 3 The phrase "and natural law"-ac juris naturae-symbolized a significant shift. The only extant evidence of Capece's curriculum, the Album

\footnotetext{
${ }^{1}$ Raffaele Iovine, "Una cattedra per Genovesi nella crisi della cultura moderna a Napoli, 1744-1754," Frontiera d'Europa 7 (2001), 359-532, at 416-32.

${ }^{2}$ For Capece's appointment see Vatican, Biblioteca Apostolica, Vat. lat. 9276, Memorie di alcuni letterati Napoletani per uso del Conte Giammaria Mazzuchelli comunicateci nel 1764 dal Sig. Francesco Daniele di Napoli, 290-91; and Giovanni Giuseppe Origlia Paolino, Istoria dello Studio di Napoli, 2 vols. (Naples, 1753-4), 2: 309.

${ }^{3}$ Gaetano Maria Capece, Opuscula nunc prima edita, 2 vols. (Naples, 1785-90).

(C) The Author(s), 2020. Published by Cambridge University Press. This is an Open Access article, distributed under the terms of the Creative Commons Attribution licence (http://creativecommons.org/licenses/by/4.0/), which permits unrestricted re-use, distribution, and reproduction in any medium, provided the original work is properly cited.
} 
professorum Regii Archi-Gymnasii neapolitani (1761-2), reveals that his teaching concentrated on the "laws of nature, or the duties of man." 4 This echoed the substance of Genovesi's De legibus naturae (1752) and it fulfilled an aspiration to align the University of Naples with its counterparts in Northern Europe, where a reforming professoriate had transformed curricular moral philosophy.

The work of Richard Tuck, Knud Haakonssen and T. J. Hochstrasser has shown how this transformation coincided with the rise of "modern natural law," or a form of moral reasoning introduced by Hugo Grotius's De iure belli ac pacis (1625). ${ }^{5}$ Brian Tierney, Francis Oakley and Terence Irwin have queried the supposed disjunction between Grotius's work and "scholastic natural law," particularly in the form propounded by the neo-Thomists who taught in the universities of Salamanca and Coimbra from the mid-sixteenth century. ${ }^{6}$ But many scholars have echoed Grotius's early admirers-Samuel Pufendorf, Jean Barbeyrac, Christian Thomasius and Gershom Carmichael-in identifying his practices as "original."7 In his Supplementum (1724) to Pufendorf's De officio hominis et civis (1673), Carmichael gave voice to this conceit by distinguishing scholastic teaching, or "empty quibblings and arguments about words," from "natural jurisprudence," or "the genuine manner of teaching moral science." 8 Thanks to the work Annabel Brett, among others, it is clear that scholastic "moral science" was more sophisticated than its depictions in the trivializing libels of its eighteenth-century critics. ${ }^{9}$ But where a salutary insistence on the ipsissima verba of the schoolmen has rightly qualified our assessment of Grotius's novelty, it should not obscure the prevalence of a belief, after 1625, that scholasticism had failed sufficiently to address "what the law of nature prescribes." ${ }^{10}$ In the paeans of his admirers, Grotius's search for a

\footnotetext{
${ }^{4}$ Album professorum Regii Archi-Gymnasii neapolitani (Naples, 1761-2), preserved as an excerpt in Fortunato Bartolomeo de Felice, Excerptum totius italicae nec non helveticae literaturae (Oct.-Dec. 1761), 273.

${ }^{5}$ Richard Tuck, “The 'Modern' Theory of Natural Law,” in Anthony Pagden, ed., The Languages of Political Theory in Early Modern Europe (Cambridge, 1987), 99-122; Knud Haakonssen, Natural Law and Moral Philosophy: From Grotius to the Scottish Enlightenment (Cambridge, 1996); T. J. Hochstrasser, Natural Law Theories in the Early Enlightenment (Cambridge, 2000).

${ }^{6}$ Brian Tierney, The Idea of Natural Rights: Studies on Natural Rights, Natural Law, and Church Law 1150-1625 (Grand Rapids, MI, 1997), 316-42; Francis Oakley, Natural Laws, Laws of Nature, Natural Rights (New York, 2005), 63-86; Terence Irwin, The Development of Ethics: A Historical and Critical Study, 3 vols. (Oxford, 2007-9), 2: 70-87.

${ }^{7}$ Samuel von Pufendorf, Specimen controversiarum circa ius naturale (Uppsala, 1678), 1-3; Jean Barbeyrac, "Préface du traducteur," in Samuel von Pufendorf, Le droit de la nature et des gens, ed. Jean Barbeyrac, 2 vols. (Amsterdam, 1706), 1: i-xcii; Christian Thomasius, "On the History of Natural Law until Grotius" (1707), in Thomasius, Essays on Church, State, and Politics, ed. and trans. Ian Hunter, Thomas Ahnert, and Frank Grunert (Indianapolis, 2007), 1-48; Gershom Carmichael, "On Moral Philosophy, or the Science of Natural Jurisprudence" (1724), in Carmichael, Natural Rights on the Threshold of the Scottish Enlightenment: The Writings of Gershom Carmichael, ed. and trans. James Moore and Michael Silverthorne (Indianapolis, 2002), 9-20.

${ }^{8}$ Carmichael, "On Moral Philosophy," 11.

${ }^{9}$ For Brett's work on this subject see (inter alia) her "Later Scholastic Philosophy of Law," in Fred D. Miller Jr and Carrie-Ann Biondi, eds., A History of the Philosophy of Law from the Ancient Greeks to the Scholastics, vol. 6, A Treatise of Legal Philosophy and General Jurisprudence, 2nd edn (Dordrecht, 2015), 335-75.

${ }^{10}$ Carmichael, “On Moral Philosophy,” 11.
} 
"common norm" of morality "for all mankind" would vitiate a position, typified by the ancient skeptic Carneades, that "justice" was artificial, or "instituted by men for their own particular advantage." ${ }^{11}$ In its place, Grotius identified a basis for a universal morality, grounded in our innate moral inclinations. Whether the scholastics had shared this ambition became increasingly irrelevant to Grotius's followers, who spurned his predecessors as "corrupted." In its initial phases, this critique was characteristically Protestant, or inclined to associate the errors of "moral science" before Grotius with the waywardness of the pre-Reformation church. ${ }^{13}$ But a significant part of Grotius's later reception was Catholic, and prone to dismiss his predecessors in a language not dissimilar to Carmichael's.

The remainder of this article focuses on this development in Naples, but its conclusions can be applied to other Catholic contexts, where the curriculum in moral philosophy was reshaped by the tropes and fixations of Grotius and his followers. ${ }^{14}$ In an insightful study of Antoine Le Grand, a Franciscan friar and missionary, Thomas Mautner has shown how Le Grand's Institutio philosophiae (1672) evolved in its second edition (1675) to incorporate "a new paradigm" of moral philosophy, in which the "eudaimonist" focus of the Aristotelian curriculum was emended by a "Pufendorfian" emphasis on "duties." within the redoubts of reformist Catholicism that emerged during the pontificate of Benedict XIV (1740-58), when the exigency of criticizing Thomas Hobbes, Pierre Bayle or collateral forms of moral skepticism gave "modern natural law" an understandable attraction for Catholics, who despaired of eudaimonism and scholastic "casuistry." In several cases, this issued in a form of Leibnizianism, especially in the mode propagated by Christian Wolff, whose confidence in post-lapsarian "reason," annexed to a genial use of scholastic sources, ${ }^{16}$ made his philosophy an ideal vehicle for the rearticulation of Thomist assumptions. ${ }^{17}$ In

\footnotetext{
${ }^{11}$ Hugo Grotius, The Rights of War and Peace (1625), ed. Richard Tuck, 3 vols. (Indianapolis, 2005), 1: 79.

${ }^{12}$ Thomasius, "On the History of Natural Law until Grotius," 43.

${ }^{13}$ Francisco Carpintero, "La modernidad jurídica y los católicos," Anuario de Filosofía del Derecho 5 (1988), 383-410. For the extent to which this critique encompassed "scholastic Protestantism," including Philip Melanchthon's Ethicae doctrinae elementa (1550), see Barbeyrac, "Préface," lxxvii; and Merio Scattola, Das Naturrecht vor dem Naturrecht: Zur Geschichte des ius naturae im 16. Jahrhundert (Tübingen, 1999), 210, 215.

${ }^{14}$ For work on these contexts see Richard Bruch, Ethik und Naturrecht im deutschen Katholizismus des 18. Jahrhunderts: Von der Tugendethik zur Pflichtethik (Tübingen, 1997); Romana Bassi, Natura, uguaglianza, libertà: Rousseau nel Settecento Veneto (Pisa, 2008); Merio Scattola, "Protestantesimo e diritto naturale cattolico nel XVIII secolo," in Giulia Cantarutti and Stefano Ferrari, eds., Illuminismo e Protestantesimo (Milan, 2010), 131-48.

${ }^{15}$ Thomas Mautner, "From Virtue to Morality: Antoine le Grand (1629-1699) and the New Moral Philosophy," Jahrbuch für Recht und Ethik 8 (2000), 209-32.

${ }^{16}$ For Wolffs "scholasticism" see Jean École, "Des rapports de la métaphysique de Christian Wolff avec celle des scolastiques," in École, ed., Autour de la philosophie wolfienne (Hildesheim, 2001), 58-60.

${ }^{17}$ For Wolffs reception by Catholics see F. L. Marcolungo, "L'eredità wolff-leibniziana nella cultura veneta tra '700 e '800," in Alfeo Valle, ed., La formazione di Antonio Rosmini nella cultura del suo tempo (Brescia, 1988), 79-130; Bruno Bianco, "Wolffianismus und katholische Aufklärung: Storchenaus Lehre vom Menschen," in Harm Kleuting, ed., Katholische Aufklärung: Aufklärung im katholischen Deutschland (Hamburg, 1991), 67-103; Dagmar von Wille, "La fortuna delle opere di Christian Wolff in
} 
Naples, Genovesi became a warm proponent of Wolffianism, ${ }^{18}$ but his commitments were eclectic, and often expressly Grotian.

The rationale for examining this development is partly its neglect in recent historiography: a florescence of work on Grotius's and his followers' later eighteenth-century reception in Naples has overlooked a crucial instantiation of this development in the earlier decades of the Settecento, omitted its curricular context, and failed to account for its principal inspirations. ${ }^{19}$ But a more urgent stimulus is a provocative claim, advanced by John Robertson in his recent work on Giambattista Vico's Scienza nuova (1725), a book of remarkable eccentricity, revised by Vico in 1730 and 1744, which remains a cynosure of scholarship on the intellectual history of eighteenth-century Naples. Robertson has argued that Scienza nuova emerged from dissatisfaction with the conventional dictates of scholasticism. ${ }^{20}$ In Vico's case, Robertson contends, the problem centered on the question of "human sociability," or the notion that humans possess inclinations, implanted by God, to live in accordance with "natural laws." The scholastic position had tended to insist on mankind's possession of a moral propensity, or the instrument in "reason" to acquire it, ${ }^{21}$ conjoined with the teleological implications of Aristotle's belief that man is a "political animal." 22 In the opening passage of $D e$ cive (1642), Hobbes famously described this "axiom" as "false," before sketching a Carneadean alternative: a society built on its inhabitants' urge to self-preservation. Hobbes's proposition fed into what Robertson-and a significant body of anglophone historiography-has described as a conflict between "neo-Stoicism" and "neo-Epicureanism." Augustine had emphasized the irremediable corruption of humanity by the Fall. In devoted admiration of Augustine's soteriology, Reformed theologians held that post-lapsarian "reason" was unable to identify a source of morality separable from exposure to Revelation. Salvation was securable by faith alone and the inscrutable operations of divine grace. JansenistsCatholic Augustinians, in nuce-embraced this interpretation of our depraved moral capacity, which they wedded to an Epicurean account of the passions. Morality was factitious and imposed to bridle the degenerate inclinations of post-

Italia nella prima metà del Settecento: la prima edizione veronese degli Opera latina," Rivista di Storia della Filosofia 50/2 (1995), 369-400.

${ }^{18}$ For this subject see Eluggero Pii, Antonio Genovesi: dalla politica economica alla "politica civile" (Florence, 1984), 11, 94, 109-10, 112, 126; Maria Teresa Marcialis, "Genovesi e Wolff," in Giuseppe Cacciatore, Vanna Gessa-Kurotschka, Hans Poser, and Manuela Sanna, eds., La filosofia pratica tra metafisica e antropologia nell'età di Wolff e Vico (Naples, 1999), 47-69.

${ }^{19}$ For a typical contribution see Maurizio Bazzoli, "Grozio nel Settecento," in Raffaele Ajello and Vittorio Conti, eds., La recezione di Grozio a Napoli nel Settecento (Florence, 2002), 43-66.

${ }^{20}$ John Robertson, The Case for the Enlightenment: Scotland and Naples, 1680-1760 (Cambridge, 2005), 201-55; Robertson, "Sacred History and Political Thought: Neapolitan Responses to the Problem of Sociability after Hobbes," Historical Journal 56/1 (2013), 1-29; Robertson, "Sociability in Sacred Historical Perspective, 1650-1800," in Béla Kapossy, Isaac Nakhimovsky, Sophus A. Reinert, and Richard Whatmore, eds., Markets, Morals, Politics: Jealousy of Trade and the History of Political Thought (Cambridge, MA, 2018), 53-81.

${ }^{21}$ For an exposition of the Thomist account see Odon Lottin, "Synderèse et conscience aux XIIe et XIIIe siècles," in Lottin, Psychologie et morale aux XIIe et XIIIe siècles, 6 vols. (Louvain, 1942-60), 2: 103-349.

${ }^{22}$ For an important qualification see Annabel Brett, Changes of State: Nature and the Limits of the City in Early Modern Natural Law (Princeton, 2011), 121. 
lapsarian man. Civil associations were "artificial" and produced in obedience to the "instinct" of self-preservation. For Jansenists, this "neo-Epicurean" position defied the scholastics' confidence in the use of "reason" to countervail the deficiencies of our Fallen nature. Hobbes's voluntarist conception of morality, his materialist ontology, and his emphasis on a self-preserving utility appeared to share several suppositions with Christianized Epicureanism. But Pufendorf's position was more ambiguous: corrupted human reason could identify the obligatory character of natural law by deducing its origin in God's will, which had enjoined the necessity of maintaining social life (socialitas). In the later seventeenth century, this form of neo-Epicureanism clashed with an emergent strand of neo-Stoicism. Grotius was responsible for the latter's first expression, in his reliance on the Stoic conception of oikeiosis or an appetitus societatis, and several of his followers, particularly Leibniz, argued that post-lapsarian reason was sufficiently adept at identifying "justice," which existed independently of convention or the mutable injunctions of a "sovereign," including God. ${ }^{23}$

In Robertson's account of Vico's motivations, Pierre Bayle's Pensées diverses à l'occasion de la comète (1682-1704) is a crux. Bayle's work was rooted in a conception of human sinfulness reminiscent of Jansenism. Only self-seeking utility and fear of punishment assured the coexistence of Fallen man. For Bayle, the experience of Revelation was not meaningfully more productive of "moral" behavior than the disincentives of corporal punishment or the compensations of obedience to social convention. Upon these premises, a "society of atheists" could coexist as peaceably as a society of Christians. According to Robertson, Scienza nuova was a response to the problem raised by Bayle's reasoning and by the "sociability problem" in general. The popularity of Jansenism was a similar mark of this development, as Vico's co-religionists dismissed the complacent teleology of human association invoked by the Thomists of the "Second Scholastic." In Robertson's account, Vico's response to this difficulty was characteristic of "Catholic" anxieties and betokened a widespread realization among Catholics that a Thomist account of civil coexistence had lost its "intellectual viability" after "1650." ${ }^{24}$ In each recension of Scienza nuova, Vico revealed how the biblical narrative of human socialization, or "sacred history," could vindicate the role of "divine providence" in guiding mankind to the benefits of civil life. In Robertson's deft handling of the evidence, the vindication of divine providence emerges as one of Vico's principal motivations. ${ }^{25}$ But it is Robertson's

\footnotetext{
${ }^{23}$ This highly condensed summary draws on Robertson, Case for the Enlightenment; Haakonssen, Natural Law and Moral Philosophy; James Moore, "Hume and Hutcheson," in M. A. Stewart and John P. Wright, eds., Hume and Hume's Connexions (Edinburgh, 1994), 23-57; Ian Hunter, Rival Enlightenments: Civil and Metaphysical Philosophy in Early Modern Germany (Cambridge, 2001); Pierre Force, Self-Interest before Adam Smith: A Genealogy of Economic Science (Cambridge, 2009); Christopher Brooke, Philosophic Pride: Stoicism and Political Thought from Lipsius to Rousseau (Princeton, 2012); Thomas Ahnert, The Moral Culture of the Scottish Enlightenment, 1690-1805 (New Haven, 2014); Simon Grote, The Emergence of Modern Aesthetic Theory: Religion and Morality in Enlightenment Germany and Scotland (Cambridge, 2017); Tim Stuart-Buttle, From Moral Theology to Moral Philosophy: Cicero and Visions of Humanity from Locke to Hume (Oxford, 2019).

${ }^{24}$ Robertson, "Sacred History," 8.

${ }^{25}$ Robertson, Case for the Enlightenment, 214 n. 32.
} 
allied contention, in which Vico's use of "sacred history" typifies a Catholic response to the decline of "scholastic natural law," which is difficult to accept.

The purpose of this article, if only par ricochet, is to show why Robertson's contention is erroneous. This is not to enter into the highly complex territory of explicating Vico's intentions: Robertson's account can speak for itself. ${ }^{26}$ Instead, it is to ask whether Robertson's capacious account of Vico's context can serve to explain the intellectual anxieties of Vico's coreligionists. It is testament to Robertson's insight that in writing about Vico he has identified a question-the fate of natural law in Catholic lands, after the "Second Scholastic"-which has been discussed only exiguously in studies of the later seventeenth and early eighteenth centuries. The following article shows how the transformation of the curriculum in moral philosophy in Naples was a development propelled, in part, by the "sociability problem," but it highlights a series of other impingements on the survival of the early modern modus vivendi between Aristotelian ethics and scholastic moral theology. In explaining how Grotius and his followers found their way into the curriculum of the University of Naples, one can begin to understand how this story played out across Europe, where Catholics were increasingly drawn to the moral reasoning of "heretics."

\section{I}

In 1703, a viceroyal decree, De regimine studiorum, introduced a chair of "moral philosophy" into the University of Naples. ${ }^{27}$ The chair was exempt from quadrennial reelection by concorsi and its tenant would be paid 180 ducati per annum, or 60 ducati more than the professors of logic, metaphysics and physics. ${ }^{28}$ The Universities of Pisa (1548-56), Bologna (1562), Rome (1566) and Ferrara (1603) had introduced professorships of moral philosophy before the eighteenth century, and the subject formed a conspicuous part of the earliest Rationes studiorum (1591-9), the model curriculum of the Jesuits. ${ }^{29}$ Prior to 1703, many Neapolitan students were exposed to the subject in seminaries and colleges. Emanuele Tesauro's Filosofia morale derivata dall'alto fonte del grande Aristotele Stagirita, originally published at Turin in 1670, was reprinted at Naples in 1673, as an aid for private instruction. The university, however, was reluctant to incorporate the subject into its curriculum. In part, this reluctance stemmed from a generic subordination of moral philosophy to logic, metaphysics and physics, or the three other branches of curricular philosophy in the quadripartite model of the discipline attributed to Aristotle. "Comprehensive" textbooks de philosophia routinely

\footnotetext{
${ }^{26}$ For examples of sophisticated, alternative interpretations of Vico's purposes see (inter alia) Paolo Cristofolini, Vico pagano e barbaro (Pisa, 2001); and Barbara Ann Naddeo, Vico and Naples: The Urban Origins of Modern Social Theory (Ithaca, 2011).

${ }^{27}$ For De regimine studiorum see Lorenzo Giustiniani, ed., Nuova collezione delle prammatiche del Regno di Napoli, 15 vols. (Naples, 1803-5), 13: 36-42.

${ }^{28}$ Francesco Scandone, L'Università degli Studi in Napoli nel Settecento: ordinamento-concorsi-locali (Santa Maria Capua Vetere, 1927), 20-21.

${ }^{29}$ For the Ratio studiorum see David A. Lines, Aristotle's Ethics in the Italian Renaissance (ca. 13001650): The Universities and the Problem of Moral Education (Leiden, 2002), 379.

${ }^{30}$ For a comprehensive study of moral philosophy in Renaissance Europe see Jill Kraye, "Moral Philosophy," in Charles Schmitt, Quentin Skinner, and Eckhard Kessler, eds., The Cambridge History of
} 
omitted philosophia moralis from their contents, but rarely excluded logic, metaphysics or physics. ${ }^{31}$ In Naples, Andrea Lao's Compendiosae totius philosophiae disputationes (1643) and Michele Franco's Universae philosophiae disputationes (1650) shared this structure, and Giuseppe de Benedictis's Philosophia peripatetica (1687-92), a four-volume compendium for Jesuit seminarians, adopted it incidentally, after subjoining a glib apology to its final page:

From the beginning of the composition of this volume-a volume that treated of metaphysics, the fourth topic to be treated according to the method prescribed by Aristotle [sc. logic, special and general physics, metaphysics]-I had intended to include an ethics, which explains why the number of volumes promised by the cover of each has been "five." But my mind was then occupied with other matters, whose causes would abuse your leisure were I to recount them, and so I must ask that you take the four volumes so far published as the Philosophia peripatetica in its entirety. ${ }^{32}$

A minor source of this reluctance was the complexity posed by the triadic format of moral philosophy. The subject, as envisioned by De regimine studiorum, was designed to expose students to Aristotle's Ethics, Politics and Economics, or to "ethics," "politics," and "economics." Many cattedratici were dutiful in their coverage of each component, but there nonetheless emerged a tendency to devote courses of "moral philosophy" to "ethics," restrictedly. ${ }^{33}$ The curriculum in "ethics" from the University of Bologna typified the approach of several institutions. Over the course of five years, students were required to attend lectures on one or more books of the Nichomachean Ethics: "De iustitia et iure" (1696-7, Book V), "De virtutibus contemplativis" (1697-8, Book VI), "De amicitia" (1698-9, Books VIII and IX), "De felicitate in universali" (1699-1700, Book I) and "De attinentibus ad virtutes morales" (1700-1, Books II, III and IV). ${ }^{34}$ "Politics" and "economics" were excluded, notwithstanding their notional place within the curriculum. In Naples,

Renaissance Philosophy (Cambridge, 1988), 303-86; Kraye, "Conceptions of Moral Philosophy," in Daniel Garber and Michael Ayers, eds., The Cambridge History of Seventeenth-Century Philosophy, 2 vols. (Cambridge, 1998), 2: 1279-1316.

${ }^{31}$ Paul Richard Blum, "Der Standardkurs der katholischen Schulphilosophie im 17. Jahrhundert," in Eckhard Kessler, Charles H. Lohr and Walter Sparn, eds., Aristotelismus und Renaissance: In Memoriam Charles B. Schmitt (Wiesbaden, 1988), 127-48, at 133.

${ }^{32}$ Giovanni Battista De Benedictis, Philosophia peripatetica tomis quinque comprehensa, 4 vols. (Naples, 1687-92), 4: sig. Cc6v: "ab initio speciali tomo, qui juxtà methodum à Philosopho praescriptam, erat ordine quartus, co[m]plecti Ethica decreveram, ut numerus voluminum, quod et frons singulorum promittit, esset quinarius. Alia deinceps occurrit mens, cujus causas si recenserem, otio tuo abuterer. Per tuam itàque humanitatem rogo, ut tomos quatuor hactenus datos, pro integro opere philosophico habeas. Erit fortassè, ut, siquidem hos tibi non omninò displicuisse intelligam, illa etiam incudi reddita aut seorsum, aut majori operi inserta exhibeam. Vale."

${ }^{33}$ Lines, Aristotle's Ethics, 48-9, 106-7. For early modern commentaries on Aristotle's Politics see Günter Frank, “Politica Aristotelis': Zur Überlieferungsgeschichte der aristotelischen 'Politica' im Humanismus und in der frühen Neuzeit," in Günter Frank and Andreas Speer, eds., Der Aristotelismus in der frühen Neuzeit: Kontinuität oder Wiederaneignung? (Wiesbaden, 2007), 325-52.

${ }^{34}$ Umberto Dallari, I rotuli dei lettori legisti e artisti dello Studio Bolognese dal 1384 al 1799, 4 vols. (Bologna, 1888-1924), 3, pt. 1: 176-97. 
the same absence is conspicuous: only one early modern prelection de politica survives in the repositories of the former kingdom. ${ }^{35}$

In practice, "ethics" was equated with "moral philosophy," and courses in ethics tended to focus on Aristotle. The length of a course could differ, and the extent of its textual coverage would depend on the instructor's preference, but courses were usually devoted to expositions of the Nicomachean Ethics, either in the form of a commentary ad litteram Aristotelis or in the form of a synoptic paraphrase. A typical Neapolitan course, delivered between November 1698 and July 1699 in a Jesuit seminary, the Collegio massimo, divided itself into three "disputations," mirroring the foci of the first book of the Nicomachean Ethics: "Of the essence of goodness," "Of the essence of happiness," and "Of the ultimate, natural end of man." The headings of the first disputation typified the contents of an early modern textbook: " $\$ 1$ What is the good? $\$ 2$ Whether the good is rightly defined with reference to the appetite? $\$ 3$ Of the other divisions of the good. $\$ 4$ What kind of honest good may be had from the appetite? $\$ 5$ Whether beauty is a type of good?” ${ }^{36}$ Other courses in ethics show the same headings and locutions, with minor differences in emphasis. ${ }^{37}$ The object, in general, was eudaimonist, or focused on the explication of what constituted eudaimonia ("happiness," or "goodness," or "flourishing"). This did not issue uniformly in a focus on Aristotle, particularly after the early seventeenth century, when courses de ethica incorporated references to the Stoics, Cicero and other ancient moralists. But it consistently accepted that the task of moral philosophy was to identify our summum bonum and the "virtues" that might conduce to its attainment. In Protestant scholasticism, a course would often commence with a eudaimonologia, which identified the objective of ethics, before turning to an aretologia, which explicated the eleven Aristotelian virtues. ${ }^{38}$ The obligatory character of practicing these virtues was not obviously resolved by the principle that we are rationally concerned about eudaimonia, "because we aim at our ultimate end, and our ultimate end is realizing our rational nature." ${ }^{39}$ Sidelining teleological necessitation, which would vitiate the inquiry $a b$ initio, ${ }^{40}$ a controversy persisted on the issue of whether a free agent is "obliged" to realize her rational nature. The question pitted

\footnotetext{
${ }^{35}$ Naples, Biblioteca Nazionale, ms. Branc. IV F 6: Tractatus politicus, in quo demonstratur, quomodo societas, ubi imperium monarchium locum habet sicut et ea, ubi optimi imperant debet institui, ne in tyrannidem labatur, et ut pax libertasq[ue] civium inviolata maneat, fos. 196r-269r. This statistic excludes Naples, Biblioteca Nazionale, ms. IV H 135-9, a seventeenth-century Philosophiae moralis compendium by Agostino Galesio, which was imported to Naples from Parma in 1734, with the remainder of the Farnese library. François Fossier, La Bibliothèque Farnèse: Étude des manuscrits latins et en langue vernaculaire (Rome, 1982), 209-11.

${ }^{36}$ Naples, Biblioteca Nazionale, ms. XV G 5, Aristotelis ethyca, fos. 1v ("De felicitas essentia, Sectio I. De bono. $\$ 1$ Quid sit bonum?”), 2v (“\$2 An bonum recté definiatur per ordinem ad appetitum”), $4 \mathrm{r}$ (“\$3 De caeteris boni divisionibus"), $5 \mathrm{r}$ (“\$4 Qualiter bonum honestu[m] se habeat ad appetitu[m]”), $6 \mathrm{r}$ (“\$5 Sitne pulchrum species boni").

${ }^{37}$ Naples, Biblioteca Nazionale, ms. VIII G 47, In librum primum moralium ad Nicomacum quaestiones, ms. Branc. IV F 6, Ethices, ms. V H 293, Disputatio tertia in secundum librum Ethicorum.

${ }^{38}$ Kraye, "Conceptions of Moral Philosophy," 1284-5.

${ }^{39}$ Irwin, Development, 2: 67.

${ }^{40}$ For a helpful examination of this problem see Annabel Brett, "Human Freedom and Jesuit Moral Theology," in Quentin Skinner and Martin van Gelderen, eds., Freedom and the Construction of Europe, 2 vols. (Cambridge, 2013), 2: 9-26, at 9-13.
} 
voluntarism against rationalism. Either the obligation stemmed from the command of a lawmaker, or it stemmed from the behavior's "naturalness," irrespective of a lawmaker's preferences. In this matter, the instructor de ethica presupposed his students' familiarity with the dicta of "moral theology," which was inculcated in a separate part of the curriculum.

This tendency nonetheless allowed Pufendorf and others to insist that eudaimonism was bereft of a theory of obligation. ${ }^{41}$ In a letter of 1688 to Thomasius, Pufendorf argued that "one should institute and manage morality not in accordance with virtues but in accordance with officia." ${ }^{2}$ The Aristotelian convention was to determine what constituted "virtue" by reference to the judgment of the wise individual, or the proposition that an action is "right" if it is what "a virtuous agent would characteristically do in the circumstances." ${ }^{\prime 3}$ From Locke's perspective, articulated in a manuscript of $c .1687$, this failed to provide a non-parochial or universalistic basis for the determinants of moral action, making "moral goodness" an "empty sound": "Without showing a law that commands or forbids them," Locke noted, "those actions which the schools here call virtues or vices, may by the same authority be called by contrary names in another country." 44 Instead, "virtue" should be construed alternatively as a means to fulfill one's officia. The lineage of this claim was Ciceronian. In De officiis, Cicero had translated kathēkonta-the Stoics' doctrine of living in accordance with our telos or reason-as officia, in which a set of rights and duties pertain to the "office" or role that we possess or inhabit. ${ }^{45}$ Pufendorfs De officio hominis et civis borrowed this conceptual vocabulary, but it eschewed the blanket identification of officia with any action that was conformable to "reason," such as politeness or prudence. Instead, it confined officia to actions that are "obligatory," or imposed by a "law." Socialitas, in this respect, was an officium. This form of voluntarism fitted into Pufendorf's sub-Epicurean assessment of our post-lapsarian rational capacity, in which social order would arise through the imposition of laws, instead of through the bridling of the passions by the unenforced cultivation of virtue. But Pufendorfs indifference to aretologia was characteristic of a generalized indifference by his followers to the "improvement or perfection of individual character." ${ }^{\prime 6}$ In its place, their emphasis fell on identifying our officia within a voluntarist meta-ethical superstructure, reinforced by non-reflective habituation to behaviors that abetted sociability. ${ }^{47}$ As Carmichael noted in 1724, this would require us to redefine moral philosophy as "the science that would direct human actions to goodness ... by showing what the law of nature prescribes, what it forbids, and what sanctions it employs to enforce its precepts." ${ }^{8}$

\footnotetext{
${ }^{41}$ The following discussion is indebted to Colin Heydt, Moral Philosophy in Eighteenth-Century Britain: God, Self, and Other (Cambridge, 2018), 21-41.

${ }^{42}$ Hunter, Rival Enlightenments, 166.

${ }^{43}$ For this formulation of the principle see Rosalind Hursthouse, On Virtue Ethics (Oxford, 1999), 30.

${ }^{44}$ John Locke, "Of Ethick in General" (c.1687), in Locke, Political Essays, ed. Mark Goldie (Cambridge, 197), 297-304, at 302.

${ }^{45}$ Jacob Klein, "Stoic Eudaimonism and the Natural Law Tradition," in Jonathan A. Jacobs, ed., Reason, Religion, and Natural Law: From Plato to Spinoza (Oxford, 2012), 57-82.

${ }^{46}$ J. B. Schneewind, "Kant and Natural Law Ethics," Ethics 104/1 (1993), 53-74, at 56.

${ }^{47}$ Heikki Haara, Pufendorfs Theory of Sociability: Passions, Habits and Social Order (Cham, 2018), 34.

${ }^{48}$ Carmichael, "On Moral Philosophy," 11.
} 
In Sidgwick's terms, it marked the introduction of a "jural" conception of ethics, in which moral ideals are "imperative," and not merely "indicative."

This characterization of scholastic ethics was widely accepted, precisely because the scholastics' conception of obligation remained within the parameters of moral theology, tout court. Courses in ethics did not typically include discussions de pecatiis and its repercussions for obligatory conduct. Moreover, their instructors did not ordinarily consider the proprieties of particular moral acts, or the examination of particular "cases of conscience"- "casuistry"-in which the communicant was presented with a dilemma and asked to justify their choice in accordance with biblical injunctions, or other religious "authorities." In 1695, a professor of moral theology in the Collegio massimo examined the implications of alms to the poor, framed in the language of obligation. ${ }^{50}$ The voluntarist-contra-rationalist dilemma was productive of interminable controversy and predictable involution. In Francisco Suárez's judgment, for example, our obligation to obey the natural law arises from a teleological vis directiva, or "directive force of reason," conjoined necessarily to the "added obligation" of God's will. ${ }^{51}$ But the effect nonetheless was to furnish the student with moral obligations to complement the "indicative" components of eudaimonism. ${ }^{52}$ Le Grand could thus claim, in his revised Institutio, that his previous lections de ethica had not discussed "the rules for human actions," 53 since instruction de actibus humanis ordinarily belonged to the cursus in moral theology. The obvious question was whether the Scriptures-or approved exegesis-could provide an exhaustive guide to sublunary obligation. In Carmichael's terms, could "Christian ethics, or morals deduced from the testimony of the Scriptures, be taught in the schools for the moral part of philosophy"? ${ }^{54}$

One solution was to distinguish moral theology and ethics on the basis of their "aims." An Institutiones theologico-moralis used by the Capuchin order in Naples made this clear in its exordium, when it noted that the "aim of ethics" was "natural beatitude, consisting in tranquility of conscience," while the "aim" of "moral theology" was "supernatural, or eternal, beatitude." 55 This could satisfy some parties, particularly if they doubted the adequacy of casuistry to confer a "tranquil conscience." But the problem of distinguishing the practices persisted. In an ironic passage of his Discussioni istoriche, teologiche, e filosofiche (1725), the Neapolitan controversialist Costantino Grimaldi mocked Giuseppe de Benedictis on precisely this point, when he alleged that de Benedictis's Lettere apologetiche in difesa alla

\footnotetext{
${ }^{49}$ Henry Sidgwick, The Methods of Ethics, 7th edn (Indianapolis, 1981; first published 1907), 105.

${ }^{50}$ Naples, Biblioteca Nazionale, ms. MS V H 115, Opuscula moralia (1695).

${ }^{51}$ Irwin, Development, 2: 29-41; Stephen Darwall, "Grotius at the Creation of Modern Moral Philosophy," Archiv für Geschichte der Philosophie 94/3 (2012), 296-325, at 302-4.

${ }^{52}$ For a variation of this point see Albert Michel, "Volontarisme," in Alfred Vacant, Eugène Mangenot, and Émile Amann, eds., Dictionnaire de théologie catholique, 15 vols. (Paris, 1899-1950), 15, pt. 2: 3309-22, at 3317.

${ }^{53}$ Mautner, "From Virtue to Morality," 219-20.

${ }^{54}$ Carmichael, "On Moral Philosophy," 13.

${ }^{55}$ Naples, Biblioteca Nazionale, ms. VII C 97, Institutiones theologico-moralis, 1-2: "Ethices finis est naturalis beatitudo, in conscientiae tranquillitate ... consistens; Ubi theologiae finis est beatitudo supernaturalis, et eternae ... Unde definiri potest [Ethica]: scientia practica, aut prudentia, quae circa actus humanos ... ad honestatis regulas ... conformandos occupatur." A copy of this manuscript (ms. VII C 60) is inscribed "Ad uso del P. Simpliciano da Napoli ... Capp[uci]no."
} 
teologia scolastica e della filosofia peripatetica (1694) had defended "two beatitudes," or "one of Christ, and the other of Aristotle": "The beatitude that Aristotle directs us towards, and that which the Holy Faith teaches us, are different. Reason requires that we believe Aristotelian and Christian morality to be different, and discordant. As much as Christian morality is true and holy, Aristotelian ethics is erroneous, and impious." 56

In the Lettere, de Benedictis allowed that Aristotle had "erred" in denying the eternity of the world, ${ }^{57}$ but the warrant of his importance was Aquinas's Summa theologiae, "which had followed the trace and path of Aristotle entirely, without missing a single step. ${ }^{" 58}$ Underlining this passage in his copy of the Lettere, ${ }^{59}$ Grimaldi responded with mordant disbelief:

The noble mind of Aquinas was not so little comprehending of the sanctity of the morality of Christ, or so taken by love of Aristotle's doctrine, that he believed he was able to reconcile the sanctity of one, with the impiety, if not the profanity, of the other, or believe that the hollow morality of an Impious thinker, would be able to serve as a rule for the discernment of the Christian virtues. ${ }^{60}$

In failing to produce a course of ethics, de Benedictis had conceded Grimaldi's implications.

As Jill Kraye has shown, the "hermeneutic gymnastics" that Aristotle's ethics demanded of its Catholic exponents were often tortuous. ${ }^{61}$ But this should not suggest that Catholics were engaged eo ipso in forging a compromise between Grimaldi's "two beatitudes." Many institutions and clergy skirted the question by refusing to accommodate Aristotelian ethics into their curriculum. In 1616, a project to reform the University of Naples had modeled itself after the Constitutiones (1584) of the University of Salamanca, ${ }^{62}$ but it had pointedly neglected to adopt the latter's use of "moral lections" within its cursus of philosophy. ${ }^{63}$ In the period after

\footnotetext{
${ }^{56}$ Costantino Grimaldi, Discussioni istoriche, teologiche, e filosofiche, 2 vols. ([Naples], 1725), 2: 216: "diversa è la beatitudine, alla quale ci conduce Aristotile, da quella, che la Santa Religione c'insegna; ragion vuole, che crediamo tra lor diverse, e discordanti la Morale Aristotelica, e la Cristiana; e quanto questa vera, e santa, tanto errante, ed empia quella."

${ }^{57}$ Giovanni Battista De Benedictis, Lettere apologetiche in difesa alla teologia scolastica e della filosofia peripatetica (Naples, 1694), 84.

${ }^{58}$ Ibid., 87.

${ }^{59}$ For this copy see Madrid, Biblioteca Nacional de España, 3/21101 (BR).

${ }^{60}$ Grimaldi, Discussioni, 2: 218: "Non era la nobil mente d'Aquino, o così poco intesa della Santità della Morale di Cristo, o così presa dell'amor della dottrina d'Aristotile, che creduto avesse, potersi accordar la santità dell'una, con la empietà, non che con la profanità dell'altra: e che la Morale tanto manchevol d'un'Empio, potesse servir di norma al discernimento delle Cristiane virtù."

${ }^{61}$ Kraye, "Conceptions of Moral Philosophy," 1281.

${ }^{62}$ Nino Cortese, "L'età spagnuola," in Francesco Torraca, Gennaro Maria Monti, Riccardo Filangieri di Candida, Nino Cortese, Michelangelo Schipa, Alfredo Zazo, and Luigi Russo, eds., Storia della Università di Napoli (Naples, 1924), 201-431, at 259-64.

${ }^{63}$ Constitutiones tam commodae aptaeque quam sancta alma Salmanticensis Academiae toto terrarum orbe florentissime (Salamanca, 1584), 20 (XVI). For the Aristotelian content of these lections see Anthony Pagden, "The Diffusion of Aristotle's Moral Philosophy in Spain, ca. 1400-ca. 1600," Traditio 31 (1975), 287-313, at 308 .
} 
1703, the same resistance endured. Within the diocesan seminary of Naples, students were not required to study Aristotelian ethics, in any form. The seminary's Regole of 1744 and 1782 required inmates to study rhetoric, logic, metaphysics, physics and moral theology, but not ethics, politics or economics. ${ }^{64}$ The catalogue of the seminary's library reflected the elision. Under the heading "Philosophia Moralis seu Ethica," it listed Boethius, but not a single Aristotelian textbook or commentary. ${ }^{65}$

From Carmichael's perspective, the reduction of moral philosophy to moral theology was suspect because it spurned the "assistance" of "reason" in "discovering and adhering to the truth"; it was an "important consideration in support of the divine origin and authority of the Scriptures that they conform with the understanding of the nature of God and the duties of men that one may gather from the nature of things by the use of right reason." ${ }^{26}$ This could perhaps answer an objection like Grimaldi's against our complete reliance on reason in lieu of Revelation, but one could still contend that the use of reason to reaffirm the truth of Scripture was unnecessary or tautological. Nevertheless, generations of Catholic moral theologians accepted Carmichael's argument, to the extent that it would grossly mischaracterize Thomism to suggest that its proponents were uninterested in whether morality was susceptible of discovery by ratiocination. ${ }^{67}$ In the most ebullient form of this theology, reason unaided by Revelation could discover God's intentions for humankind, reaching to the cultivation of a nonparochial summum bonum or a determinate set of our officia as God's creatures. ${ }^{68}$ To a Jansenist, this specious confidence in the power of pure reason shaded into Pelagianism and diminished the significance of Christ's atonement, amounting potentially to the Socinians' attenuated Christology, in which Christ was portrayed merely as "a moral teacher." 69 Catholics typically occupied a space between the extremes of Jansenism and Pelagianism, and rebuffed what Benjamin Straumann has described as Grotius's principal innovation: a "quasi-jural" non-teleological rationalism, in which laws are obligatory by "their inherent (natural) rightness" instead of their origination in God's will or in their conducement to the summum bonum. $^{70}$ This ultrarationalism anticipated Kant's claim that "natural morality must be so constituted that it can be thought independently of any concept of God, and elicit our most zealous devotion solely on account of its own inner worth and

\footnotetext{
${ }^{64}$ Regole del seminario napoletano (Naples, 1744), 64-8; and Regole del seminario napoletano (Naples, 1782), 63-6.

${ }^{65}$ Naples, Biblioteca della Pontificia Facoltà Teologica dell'Italia Meridionale, Sezione "San Tommaso," ms. A. 3. 2, Catalogus bibliothecae domesticae Josephi Spinelli (1749), p. 75.

${ }^{66}$ Carmichael, "On Moral Philosophy," 13.

${ }^{67}$ R. A. Armstrong, Primary and Secondary Precepts in Thomistic Natural Law Teaching (The Hague, 1966), 21-55.

${ }^{68}$ This, in part, was the focus of the "Chinese rites controversy": Sergio Zoli, "Le polemiche sulla Cina nella cultura storica, filosofica, letteraria italiana della prima metà del Settecento," Archivio Storico Italiano 130/3 (1972), 409-67.

${ }^{69}$ Sarah Mortimer, Reason and Religion in the English Revolution: The Challenge of Socinianism (Cambridge, 2010), 24.

${ }^{70}$ Benjamin Straumann, Roman Law in the State of Nature: The Classical Foundations of Hugo Grotius' Natural Law (Cambridge, 2015), 86.
} 
excellence," ${ }^{71}$ and it predictably offended the most basic suppositions of Thomist moral theology, which remained-à la Suárez-complicatedly voluntarist and teleological. ${ }^{72}$

But it was not difficult for Catholics to recognize the attraction of Grotius's-or, indeed, Pufendorf s-project, when set against three interrelated developments. The first was the rise of moral skepticism. ${ }^{73}$ The diversity of the world's rites and customs required a minimalist consensus about our moral inclinations. This would confute the heresy that morality was factitious. Such an impulse was epitomized by Pufendorf's claim that he intended to "abolish in natural law all theological controversies, and adapt it to the understanding of the whole of mankind, who disagreed in many different ways over religion." 74 This non-confessional universalism held an additional appeal to Barbeyrac, who could use Grotius's and Pufendorf's minimalist consensus to undergird a vision of religious pluralism. ${ }^{75}$ The exiguous tradition of Catholic ecumenism could draw upon the same resource, bolstered by Grotius's ambition of reuniting the confessions, ${ }^{76}$ if not the widely bruited myth that he had died a penitent Catholic. ${ }^{77}$ But the appeal of dismantling moral skepticism did not require an irenic commitment to the ecclesia universa. The second development was the failure of eudaimonist ethics to provide a system of officia derivable from the use of reason. This was a necessary correlate of the first development, but it did not entail the wholesale rejection of eudaimonism. The polysemous character of Grotius's work could be interpreted as a hybrid of eudaimonism and "jural" ethics, in which we are minimally obliged to respect each other's "rights," but simultaneously expected to cultivate "the traditional virtues." 78 Straumann's proto-Kantian Grotius would regard the latter as supererogatory, but many readers could plausibly interpret Grotius-or his supposed epigone, Wolffas a neo-Stoic virtue ethicist, enjoining our realization of the summum bonum to ensure a teleology of sociable life. ${ }^{79}$

The third development was the generic subsidence of moral theology into the casuistry of "probabilism." If post-Tridentine moral theology had insisted on our

\footnotetext{
${ }^{71}$ Immanuel Kant, "Vorlesungen über Rationaltheologie," in Kant, Gesammelte Schriften (Berlin, 1902-), 28, 2.2: 988-1529, at 1002; translated in Kant, Lectures on Philosophical Theology, trans. Allen W. Wood and Gertrude M. Clark (Ithaca, 1978), 31.

${ }^{72}$ For a classic exposition of this point see Gerhard Hartung, Die Naturrechtsdebatte: Geschichte der Obligatio vom 17. bis 20. Jahrhundert (Freiburg and Munich, 1998).

${ }^{73}$ This should not imply that this was Grotius's principal aspiration, but merely that this was an eligible interpretation of his purposes. Robert Shaver, "Grotius on Scepticism and Self-Interest," Archiv für Geschichte der Philosophie 78/1 (1996), 27-47; Thomas Mautner, "Grotius and the Skeptics," Journal of the History of Ideas 66/4 (2005), 577-601.

${ }^{74}$ Hochstrasser, Natural Law Theories, 70.

${ }^{75}$ T. J. Hochstrasser, "Conscience and Reason: The Natural Law Theory of Jean Barbeyrac," Historical Journal 36/2 (1993), 289-308.

${ }^{76}$ G. H. M. Posthumus Meyjes, "Hugo Grotius as an Irenicist," in The World of Hugo Grotius (15831645) (Amsterdam, 1984), 43-62.

${ }^{77}$ For the origin of this myth see Jean Lévesque de Burigny, Vie de Grotius, 2 vols. (Paris, 1752), 2: 224-5.

${ }^{78}$ Tierney, Idea of Natural Rights, 324.

${ }^{79}$ For variations of this interpretation see Tobias Schaffner, "The Eudaemonist Ethics of Hugo Grotius (1583-1645): Pre-modern Moral Philosophy for the Twenty-First Century?", Jurisprudence 7/3 (2016), 478-522, at 507, 513; Johann Olsthoorn, "Grotius on Natural Law and Supererogation," Journal of the History of Philosophy 57/3 (2019), 443-69.
} 
post-lapsarian rational capacity, it set this concession against a bewildering variety of qualifications about the possibility of volitional misconduct. A genre of casuistry subsequently burgeoned, applying to cases in which the subject was insufficiently apprised of whether an action was unlawful. Probabilism allowed the subject to perform an action if it was supported by an "authority," notwithstanding her perception that the performance was liable to infringe a law. This position was favored by the Jesuits after its endorsement by Suárez and Gabriel Vázquez, and it was bitterly contested by rival religious orders. "Probabiliorist" reasoning-favored by the Dominicans after 1656-allowed an action that potentially infringed a law if the probability of noninfringement was "greater." "Equiprobabilist" reasoning allowed an action that potentially infringed a law if the probability of infringement and noninfringement was the "same." Jansenist adherence to "rigorist" or "tutiorist" reasoning - in which noninfringement was assured-attracted a form of Jesuit criticism that was cast by opponents as a defense of moral "laxity." 80 In Catholic Europe, seventeenth- and eighteenth-century moral theology mutated into a debate over probabilism. In 1695 Giuseppe de Benedictis published a refutation at Pozzuoli of Pascal's Lettres provinciales (1656-7), defending the Jesuits' probabilist leanings against the rigorism of Port Royal. ${ }^{81}$ In 1743 the Dominican Daniele Concina published a defense of probabiliorism at Lucca, eliciting a series of Jesuit responses at Venice and Pesaro. In the same decade, the influential casuistic of Alfonso de' Liguori appeared at Naples, guiding his order of "Redemptorists" to an equiprobabilist via media. ${ }^{82}$ These debates had the predictable effect of alienating reformist Catholics, who could more assertively doubt the aptitude of moral theology to inform communicants of their officia. This did not require these reformists to share Barbeyrac's belief that morality might be a "demonstrable moral science"; as the latter complained in 1706 , "many maintain that morality is a science very uncertain, in which hardly anything beyond probabilities is to be found," alluding to the shibboleth on certitudo moralis in moral theology-originating in the Nicomachean Ethics (1094b) and popularized by Jean Gerson-in which it was denied that "strict demonstration" analogous to mathematics was possible for the moralist. ${ }^{83}$ Instead, it merely reconfirmed the principle that our moral duties could be accessible via reason, without the mediations of a casuist. More urgently, perhaps, probabilism compounded a suspicion of the Jesuits' antinomian tendencies, insofar as it was interpreted to endorse disobedience to secular laws on the strength of an approved "authority." As Paolo Prodi has argued, Liguori's popularity in Naples stemmed from the submissive implications of equiprobabilism, which Liguori shrewdly admixed with an insistence that moral theology should pertain

\footnotetext{
${ }^{80}$ This crudely summarizes an intricate set of distinctions, which are explained in detail by Stefania Tutino, Uncertainty in Post-Reformation Catholicism: A History of Probabilism (Oxford, 2018).

${ }^{81}$ Pasquale Sposato, Le Lettere provinciali di Biagio Pascal e loro diffusione a Napoli durante la "revoluzione intellettuale" della seconda metà del secolo XVII (Tivoli, 1960), 25-47.

${ }^{82}$ For Liguori's casuistic and its influence see Louis Vereecke, De Guillaume d'Ockham à Saint Alphonse de Liguori (Rome, 1986), 553-94.

${ }^{83}$ Tuck, "The 'Modern Theory'," 108. For certitudo moralis see Sven K. Knebel, Wille, Würfel und Wahrscheinlichkeit: Das System der moralischen Notwendigkeit in der Jesuitenscholastik 1550-1700 (Hamburg, 2000), 55.
} 
only in foro conscientiae - the parameter incised by the papal bull In eligendis (1562) - and not in civil affairs or in munere alieno. ${ }^{84}$

In combination, these three developments provided "modern natural law" with a significant purchase in Naples, where the secular authority of the Bourbon crown was increasingly assertive of its "regalist" entitlements against the specter of hierocratic papalism. It would be tempting to associate this story with a form of "secularization," in which the reception of Grotius marks the emergence of a "civil philosophy," inaugurating a process akin to Thomasius's vision of forging "a radical separation of moral theology from politics and law," as Ian Hunter has argued. ${ }^{85}$ However, the use of "modern natural law" in Naples was never nominally "desacralizing." If it did not seek to fortify a regalist ecclesiology, it was solicitous of a religion that conventional resources-moral theology or unreconstructed eudaimonism-were no longer equipped to defend.

\section{II}

This was the context of a decree of June 1732, when-as one of his first acts as cappellano maggiore-Galiani created a professorship in the "Law of Nature and Nations." ${ }^{\prime 86}$ The creation coincided with a prospective vacancy in the cattedra of ethics, which had reportedly attracted inadequate cattedratici after 1703. A letter sent in early 1714 by the municipal electors of Naples to the cappellano maggiore, Diego Vincencio de Vidania, complained about the subject, noting that it had appealed excessively to indifferent students, or those "who study only to eat." ${ }^{87}$ A response, sent by Vidania's adjutant, explained that the cattedratico of ethics, Diego de Loya, could not "be well understood by his students, because of his pronunciation." ${ }^{88}$ De Loya was the cattedra's second incumbent (1705-20), after the inaugural professor Ottavio Santoro (1703-5). De Loya's temporary replacement, Arcangelo Maria Ciccarelli, would lose a concorso in 1721 to Niccolò Crescenzo, formerly a professor of logic, who subsequently held the cattedra from 1721 until his death in 1734, when the medical doctor Giacinto Giannotti requested it per l'interim. In a letter to the king of Naples, Galiani questioned Giannotti's credentials

\footnotetext{
${ }^{84}$ Paolo Prodi, Una storia della giustizia: dal pluralismo dei fori al moderno dualismo tra coscienza e diritto (Bologna, 2000), 381; Maria Grazia Maiorini, "Tanucci, S. Alfonso e la teoria della sovranità," Rivista del Sannio 22 (2004), 184-238. For a distinctive discussion of this issue see Raffaele Ajello, Arcana Juris: diritto e politica nel Settecento italiano (Naples, 1976), 346-7.

${ }^{85}$ Hunter, Rival Enlightenments, 7.

${ }^{86}$ Federico Amodeo, "Le riforme universitarie di Carlo III e di Ferdinando IV Borbone," Atti dell'Accademia Pontaniana 32 (1902), 1-30, at 4, 8.

${ }^{87}$ Naples, Biblioteca Nazionale, ms. XI B 17, Diego Vincencio de Vidania, Consulta (28 Sept. 1714), fo. 279r, printed in Dario Luongo, ed., All'alba dell'Illuminismo. Cultura e pubblico studio nella Napoli austriaca: Contegna, Vidania, Caravita, Giannone (Naples, 1997), 103: “[e]sta cathedra está fundada sino aplican los estudiantes que solamente trabajan para comer."

${ }^{88}$ Naples, Biblioteca Nazionale, ms. XI B 17, Filippo Caravita, Consulta, fo. 285r-v, printed in Giuseppe De Blasiis, "L’Università in Napoli nel 1714," Archivio Storico delle Province Napoletane 1 (1876), 141-66, at 153: "Si possiede [sc. la Cattedra di Etica] per concorso P. F. Diego Loya Agostiniano, ma tiene pochissimi Scolari, si perchè il Professore non sta in molto credito si anche perchè la sua pronuncia non è bene intesa da' Studenti."
} 
for the post, "even for the time being [etiam ad tempus]," 89 and reminded the court of an alternative to Giannotti's appointment:

On this occasion, I ought to mention that two years ago, when lessons in the law of nature and nations were introduced into the University, a subject which contains the true principles of ethics ... it was suggested that the chair of ethics ... be suppressed in order to create some other chair, of which the University had a pressing need.

In closing the letter, Galiani reiterated his plea to "abolish the chair of ethics, obliging the professor of the law of nature and nations to teach the material that the professor of ethics had taught." 90 The plea, requiring the approval of the king himself, was rebuffed. ${ }^{91}$ But it signaled an important rupture with the convention that a curriculum in "moral philosophy" would require a restricted focus on Aristotle's Ethics.

One impetus for Galiani's request was financial. He had hoped to install Pietro de Martino in a professorship of astronomy by appropriating a portion of the salary from the abolished cattedra of ethics. ${ }^{92}$ This fitted into Galiani's broader program of natural-scientific reformism, in which he promoted professors who were sympathetic to Newtonianism and sponsored an Accademia delle Scienze. ${ }^{93}$ But a separate impetus was the extent to which the reform appealed to Galiani's private anxieties about the challenge of moral skepticism. ${ }^{94}$ In c.1721 Galiani completed a manuscript on "moral science." In fair copy, he entitled it Ricerche intorno alle

\footnotetext{
${ }^{89}$ Naples, [a]rchivio di [s]tato, Cappellano Maggiore, Relazioni, 718/VII, fo. 92r: "essendo ... D[ottor]e Giannotti attualm[en]te Professore di Medicina, $n$ [on] istimo utile dell'Un[iversi]tà, che gli si faccia insegnare, etia[m] ad tempus, l'Etica, la Politica e la Morale, [deleted: perché queste non son] discipline affatto disparate dalla professione sua."

${ }^{90}$ Naples, AS, Cappellano Maggiore, Relazioni, 718/VII, fos. 92v-3r: "Con tal occas[io]ne poi debbo riferire a M[aestà] S[ua] Ill[ustrissi]ma, che da due anni a questa parte essendosi introdotta in questi Studj pubblici la lezione del diritto della natura e delle genti, che contiene i veri principj [deleted: dell'Etica, della Morale] dell'Etica ... si pensava supprimere la ... Cattedra di Etica ... p[er] fondarne qualche altra, di cui avesse maggior bisogno l'Un[iversi]tà ... io sarei di parere ... di estinguere la d[etta]a cattedra di Etica, con imporre al professore del diritto della natura e delle genti, che nelle sue lez[io]ni insegnasse anche le materie, che in q[ue]lla si trattavano."

${ }^{91}$ Amodeo, "Le riforme universitarie," 17, reports that the cattedra was "abolished" in "1734," but a professor, Giuseppe Lopez, was appointed in that year. Luigi Capuano, Notizie intorno alla origine, formazione e stato presente della $R$. Università di Napoli (Naples, 1884), 18. Romano Gatto, Libri di matematica a Napoli nel Settecento (Rome, 2010), 53, reports that the chair was "abolished" in "1738," but Lopez's successor, Isidoro Sanchez de Luna, held the professorship from 1735 until 1746. Scandone, L'Università, 26, 37.

${ }^{92}$ Francesco Cammisa, L'Università di Napoli nella seconda metà del '700: Documenti e profilo delle riforme (Naples, 2001), 190-91; Imma Ascione, Seminarium doctrinarum: L'Università di Napoli nei documenti del '700, 1690-1734 (Naples, 1997), 344.

${ }^{93}$ For Galiani's scientific reformism see Vincenzo Ferrone, Scienza, natura, religione: mondo newtoniano e cultura italiana nel primo Settecento (Naples, 1982).

${ }^{94}$ For discussions of the Ricerche see ibid., 354-8, 362-6, 411-12, 424-5, 427-30, 432-8, 440-41; Koen Stapelbroek, Love, Self-Deceit, and Money: Commerce and Morality in the Early Neapolitan Enlightenment (Toronto, 2008), 56, 65-85; Robertson, Case for the Enlightenment, 204-6.
} 
prime origini della scienza morale, ${ }^{95}$ and marked both extant versions as private, or "solo per mio uso." ${ }^{\text {"96 }}$ A decade earlier, Galiani had begun to practice as a lector in moral theology within the monastery of San Eusebio, the seat of the Celestine Order in Rome. The terms of his appointment had encompassed instruction on the Sacred Scriptures, and this formed the basis of his Conclusiones selectae ex historia veteris testamenti (1708), a printed set of disputations, partly on the textual history of the Septuagint, which were quickly censured by the Congregation of the Index. ${ }^{97}$ Galiani's further Conclusiones on dogmatic controversies-"de locis theologicis," "de Trinitate," "de Incarnatione," "de Sacramentis," and "de Gratia" a pointed disinterest in the nominal purpose of his position, or "moral theology" per se. By 1725, Galiani was ordering works by Pufendorf from the lausannois bookdealer Marc-Michel Bousquet. ${ }^{99}$ In the following year, he was reportedly offering private tutelage in "Moral Philosophy and the Principles of the Law of Nature." 100

The Ricerche begin with man's "first state [ primiero stato], as he was in that first and coarse age." ${ }^{\text {101 }}$ Galiani asks his reader to concede the biblical narrative of the creation of humankind, but to "suppose" an "uninhabited, and uncultivated earth," in which an "adult man" occupied the condition of a "child": "utterly unequipped with any ideas, or any information [notizia]," and deprived "of all his senses." 102 The object is to survey how this man advanced "in the cognition of things." Through experience and reflection upon his surroundings, the man notices that actions entrain pleasurable or painful consequences. He averts pain and seeks pleasure. This is an "instinct." ${ }^{103}$ In noticing the advantages of society, he cohabits with others and communicates his thoughts. ${ }^{104}$ This is another "instinct." ${ }^{105}$ In observing the world's perfection, he infers the omnipotence of its author, and intuits the laws that bind him. ${ }^{106}$ These "instincts" are not innate "ideas," but derive from the

\footnotetext{
${ }^{95}$ Naples, [S]ocietà Napoletana di Storia [P] atria, ms. XXXI B 1, fos. 197r-249r and ms. XXX C 16, fos. $1 \mathrm{r}-68 \mathrm{r}$.

${ }^{96}$ Naples, SP, ms. XXXI B 1, fo. 197r and ms. XXX C 16, fo. 1r.

${ }^{97}$ Gustavo Costa, Celestino Galiani e la Sacra Scrittura: Alle radici del pensiero napoletano del Settecento (Rome, 2011).

${ }^{98}$ Maria Natale, "Ecletticismo teoretico e pragmatismo, alle origini delle riforme illuministiche: L'autobiografia di Celestino Galiani," Frontiera d'Europa 1 (2002), 115-219, at 176-9, 181-7.

${ }^{99}$ Naples, SP, ms. XXXI A 2, fos. 86r-96v. An earlier letter, addressed to the apostolic nuncio in Brussels, intimates that Galiani had attempted to import a work by Pufendorf before 1715 (ms. XXXI B 1, fo. 291r). He had demonstrably read Grotius's Annotationes ad Vetus Testamentum (1644) before c.1710 (ms. XXX D 2, fo. 215r).

${ }^{100}$ Natale, "Ecletticismo," 216-17.

${ }^{101}$ Naples, SP, ms. XXX C 16, fo. 1r.

${ }^{102}$ Ibid., fo. 1r-v: "Quantunque il vero principio del mondo, e della natura umana sia stato tal quale nella Sacra Scrittura si descrive: noi nella dimeno per nostra maniera d'intendere e per dedurne ciò che andiamo ricercando, supporremo, che in questa terra tal quale ella è ... disabitata, ed incolta, un uomo adulto sì, ma della condizione di un fanciullo, che nasce, vi si trovi, e cominci ad essere. Questo primo uomo, che viene al mondo sfornito affatto d'ogni idea, e d'ogni notizia ... de' suoi sensi, de' quali si suppone privo."

${ }^{103}$ Ibid., fo. $17 \mathrm{v}$.

${ }^{104}$ Ibid., fo. $6 \mathrm{r}$.

${ }^{105}$ Ibid., fo. $18 \mathrm{r}-\mathrm{v}$.

${ }^{106}$ Ibid., fos. $11 \mathrm{r}-13 \mathrm{r}$.
} 
use of reason. ${ }^{107}$ In using his reason, the man acquires the notion of "virtue" and its two forms: "physical virtue" (pleasure-inducing) and "moral virtue" (ruleconforming). 108 "Moral good," he discovers, "properly consists in nothing other than a habit or faculty of acting in conformity with certain laws." ${ }^{109}$ In observing the law, the man satisfies his propensity for pleasure, annexed to a God-fearing consequentialism. He reasons that his soul is immortal and susceptible of eternal punishment. ${ }^{110}$ These are the "first origins of moral knowledge." Where virtue consists in conformity to a law, and a law requires a legislator, it would be erroneous to assume that an individual, without an idea of God, could act virtuously. ${ }^{111} \mathrm{He}$ could follow a propensity to be sociable, satisfying a deeper propensity to conserve himself. ${ }^{112}$ But he would never prefer "moral virtue" to "physical virtue": "No progress may be made in moral knowledge [scienza morale], unless man's ultimate end is first established, and whether his hopes are restricted entirely to this life, or to another-where there may be space to hope or fear rewards and punishments even after death."113 In order to answer Bayle, whose work Galiani cited expressly, ${ }^{114}$ it was necessary to establish that there could no moral virtue without God. $^{115}$

Readers of Galiani's Ricerche would have recognized how it differed from conventional moral theology. The Ricerche presupposed the truth of the Scriptures ("the true origin of the world, and of human nature, is that which the Sacred Scriptures describe"), but it neglected to explain how these truths ramified into moral prescriptions. In its voluntarist definition of "moral virtue," as obedience to the officium of conforming to a law, the Ricerche placed an additional filter between its conclusions and those of curricular Aristotelianism. The divergence between Galiani's preferences and the pedagogy of moral philosophy in the University of Naples, $c .1732$, was profound. The surviving remnants of the university's curriculum in the early eighteenth century-Diego de Loya's Quinque porticus morales ad probaticam piscinam mysticae sanitatis (1717) and Giuseppe Maria Amati's Ethica ex-tempore concinnata in publica universitate neapolitana (1721) -

${ }^{107}$ Ibid., fos. $40 \mathrm{v}-1 \mathrm{r}$.

${ }^{108}$ Ibid., fo. $60 \mathrm{r}$.

${ }^{109}$ Ibid., fos. 9v-10r: "la virtù propriamente in altro non consistendo, che nell'abitudine o sia facultà di operar conformemente a certe leggi e vice versa il vizio nell'operar difformemente alle medesime."

${ }^{110}$ Ibid., fos. $21 \mathrm{v}, 23 \mathrm{r}$.

${ }^{111}$ Ibid., fo. $10 \mathrm{v}$.

${ }^{112}$ Ibid., fos. $4 \mathrm{r}-\mathrm{v}, 18 \mathrm{r}-\mathrm{v}, 20 \mathrm{v}, 21 \mathrm{v}$.

${ }^{113}$ Ibid., fo. $23 \mathrm{v}$ : "niun progresso può farsi nella scienza morale prima che siasi certamente stabilito l'ultimo fine dell'uomo, e se le sue speranze si restringan tutte in questa vita, oppure passino di là, e vi sia luogo da sperare, e temer premio, e gastigo anche dopo la morte."

${ }^{114}$ Ibid., fo. 63v, translating Pierre Bayle, "Arcesilas," in Bayle, Dictionnaire historique et critique, 4 vols. (Rotterdam, 1720), 1: 286 n. (k). This phrase does not appear in the Dictionnaire's first (1697), second (1702), or "third" edition (1715). The pagination in Galiani's reference to the Dictionnaire ("Bayle p. 286") does not correspond to the Dictionnaire's 1730,1734, 1738 or 1740 editions, and thus it must refer to the 1720 edition.

${ }^{115}$ It should be clear that Galiani's Ricerche is hardly a "secular theory of utility based on a hedonistic individualism," pace Richard Bellamy, "Da metafisico a mercatante': Antonio Genovesi and the Development of a New Language of Commerce in Eighteenth-Century Naples," in Anthony Pagden, ed., The Languages of Political Theory in Early-Modern Europe (Cambridge, 1987), 277-302, at 298. 
were devotedly Aristotelian, without any reference whatsoever to Grotius or natural law. Amati's work examined seriatim the contents of the Nicomachean Ethics. ${ }^{116} \mathrm{De}$ Loya's shared this structure but devoted a significant portion of its text to hieroglyphics and ancient coinage. ${ }^{117}$ Beyond the confines of the university, published moral philosophy in Naples, such as Giovanni Ghirardi's Riflessioni morali sopra l'etica, ed economica (1733), tended to adopt the same format, or disconcertingly confounded its parameters with moral theology. Ghirardi, the Bishop of Montemarano, defined "ethics" as a "cognition" fitted for "beatitude": "directing Man unto the road of perfection ... revealing to him the method that he ought to adopt against the satisfaction of the blind senses by the body, and ... elevating him, through his reason, to eternal life."118

The works of Grotius, Pufendorf, and their followers were not unknown before 1732. The Neapolitan jurist Francesco d'Andrea had cited Grotius approvingly in 1676. ${ }^{119}$ In 1712, Vidania completed a Thomist confutation of Grotius in a manuscript entitled $E l$ derecho natural innato. ${ }^{120}$ Before c.1740, the Biblioteca Brancacciana, a major public library in the center of Naples, preserved three copies of De iure belli ac pacis in a section marked "libri prohibiti." ${ }^{21}$ By April 1733, Pietro Giannone, writing in exile from Vienna, could recommend that the University of Naples incorporate a curriculum in the "law of nature and nations," structured in explicit imitation of Grotius's masterwork. ${ }^{122}$ Vico himself discussed Grotius at length in Il diritto universale (1720-2) and the first two recensions of his Scienza nuova, in obvious expectation of his readers' familiarity with Grotius's arguments. He reportedly taught Grotius's work in his scuola privata, ${ }^{123}$ he almost certainly was involved in a pirated Neapolitan edition of De iure belli ac pacis in $1719,{ }^{124}$ and he appears to have commenced a detailed commentary on the latter,

\footnotetext{
${ }^{116}$ Giuseppe Maria Amati, Ethica ex-tempore concinnata in publica universitate Neapolitana ... (Naples, 1721), 40 ("Felicitas formalis in hac vita habetur per amorem Dei, ut fontis totius virtutis, et honestatis"), 49 (“2. Ad adjutoriis felicitatis"), 57 (“De virtutibus. Quid sit virtus?”), 64 (“De proprietatibus virtutis"), 71 (“De causis, et divisione virtutum moralium"), 73 (“De prudentia"), 88 (“De fortitudine”), 115 (“De justitia"), 135 ("De temperantia"), 148 ("De passionibus animi").

${ }^{117}$ Amati, Ethica, 9, 11, 127, 219, 260; and Diego de Loya, Quinque porticus morales ad probaticam piscinam mysticae sanitatis, 2 vols. (Naples, 1717).

${ }^{118}$ Giovanni Ghirardi, Riflessioni morali sopra l'etica, ed economica (Naples, 1733), 35: "l'Etica, che per dirigere l'Uomo nella via della perfezione, l'apre il sentiero, che dee intraprendere contro la sodisfazione de' sensi acciecati dal corpo ... lo fà sollevare per la ragione a i beni eterni."

${ }^{119}$ Salvo Mastellone, "Grozio e il pensiero giuridico politco a Napoli nella seconda metà del Seicento," in La storia del diritto nel quadro delle scienze storiche (Florence, 1966), 491-6.

${ }^{120}$ Víctor Tau Anzoátegui, "Fragmento de una cultura jurídica desaparecida: un manuscrito del español Vidanía sobre derecho natural (1712)," Quaderni Fiorentini, 24 (1995), 157-98.

${ }^{121}$ Naples, Biblioteca Nazionale, ms. Branc. II G 14, Inventario de' libri prohibiti della libraria Brancaccio, fos. $15 \mathrm{r}, 21 \mathrm{r}, 64 \mathrm{v}$.

${ }^{122}$ Luongo, All'alba, 146-7; and Paola Negri, “The Reputation of Grotius in Italy," Grotiana 20/1 (1999), $49-75$, at 70 .

${ }^{123}$ For this claim see Gherardo de Angelis, Vita di Gherardo de Angelis dell'Ordine de' Minimi, da lui stesso descritta ([Naples], [ante 1783]), ix-x.

${ }^{124}$ For this claim see Dario Faucci, "Vico editore di Grozio?," Giornale Storico della Letteratura Italiana 136 (1959), 97-104.
} 
only to have stopped "when, on reflection, he thought it was not fitting for a man of Catholic faith to adorn with notes the work of a heretical author." ${ }^{25}$ Yet this engagement with Grotius or his followers was exceptional. The monuments of "modern natural law" were excluded from the curricula of the kingdom's seminaries and collegi, including the lezioni of its literary academies, ${ }^{126}$ and domestic republications or translations of Grotius's or his followers' work did not appear until the 1750s, ${ }^{127}$ when their books were included in the first printed edition of the Brancacciana's Catalogus, in spite of their presence-excepting Wolff-on the Index librorum prohibitorum. ${ }^{128}$

This partly explains Galiani's impatience with the retrograde curriculum in moral philosophy in 1732, and why he would support Antonio Genovesi's candidacy for the cattedra in 1746. Genovesi had arrived in Naples in 1738, shortly after completing his training for the priesthood in Salerno. He became a private tutor in 1739, audited Vico's classes in rhetoric, and published the first volume of an Elementa metaphysicae in 1743. The work consisted in a summary of the irreligious metaphysical propositions of several oltremontani-Hobbes, Gassendi, Spinoza, Locke-in a style that clerical critics felt was insufficiently hostile. Censured by the Cardinal of Naples, Genovesi found protection from Galiani, who commended a manuscript work on "ethics" that Genovesi had shared with a small group of acquaintances. In his unpublished Autobiografia (c.1755), Genovesi discussed its formulation as follows:

I studied the Law of Nature [diritto naturale]. I had already read the books of Plato, Aristotle and Cicero, and works by the Stoics touching on this material. But I immediately turned to Grotius's De jure belli ac pacis, to which I added the great work of John Selden and Samuel Pufendorf. Not much later, I added what remarkable things Christian Wolff, Johann Heinrich Boeckler, Johann Gottlieb Heinecke, and other ultramontane authors had contributed to the subject ... I was not content with all that I had read, and so I conceived of a new system of ethics, which I wrote and offered to some friends for comment. $^{129}$

\footnotetext{
${ }^{125}$ Giambattista Vico, Vita di Giambattista Vico scritta da se medesimo, ed. Rita Verdirame (Naples, 2000), 102; Vico, Varia: il De mente heroica e gli scritti latini minori, ed. Gian Galeazzo Visconti (Naples, 1996), 9-10.

${ }^{126}$ For a typical exposition of "natural law" in this context see Nicola Capasso, "Se la Ragion di stato possa derogare alla legge Naturale" (c.1697-8), in Michele Rak, ed., Lezioni dell'Accademia di Palazzo del duca di Medinaceli, 5 vols. (2000-5), 4: 82-90, which does not refer to Grotius, his followers, or any published authorities.

${ }^{127}$ For an overview of this development see Elisabetta Fiocchi Malaspina, "The Circulation of the École romande du droit naturel in Eighteenth-Century Italy," in Simone Zurbuchen, ed., The Law of Nations and Natural Law 1625-1800 (Leiden, 2019), 304-26.

${ }^{128}$ Bibliothecae S. Angeli ad Nidum ... Catalogus (Naples, 1750), 142 (Grotius), 149 (Heinecke), 250-51 (Pufendorf), 328 (Wolff); J. M. De Bujanda, Index librorum prohibitorum, 1600-1966 (Montreal, 2002), 408-10 (Grotius), 429 (Heinecke), 731-2 (Pufendorf).

${ }^{129}$ Paola Zambelli, "La prima autobiografia di Antonio Genovesi," Rivista Storica Italiana 83/3 (1971), 633-87, at 660: "Questa inclinazione lo spinse allo studio del diritto naturale. Egli avea già letto i libri di Platone, d'Aristotele, quei di Cicero e qualche cosa de' stoici toccante cotal materia. Subito s'accinse alla lettura de' libri di Grozio De jure belli et pacis, a cui tosto aggiunse l'opera grande di Giovan Seldeno e
} 
In an earlier draft of his Autobiografia (c.1748), Genovesi insisted that his method of teaching "ethics" was superior to "the previous masters of ethics within the University, who did not possess those cognitions, and that eloquence, which their profession required." ${ }^{130}$ However, a particular puzzle has surrounded Genovesi's claim that he vouchsafed his "nuova sistema d'etica" to Giuseppe Pasquale Cirillo, a professor of civil law who served, after 1747, as the professor of the law of nature and nations. ${ }^{131}$ Cirillo would later criticize Genovesi in unusually harsh terms, and Genovesi would duly mock Cirillo in a series of imagined Dialoghi (c.1766). But before this contretemps, Cirillo had apparently "commended" Genovesi's "system" and "encouraged him to complete it."132

The confusion is only deepened by the surviving prolegomenon to an undated tract on the ius naturae et gentium, in which Cirillo clearly distinguished the subject from "ethics":

The purest definition of natural law is the will of God, promulgated to the human race through right reason, commanding certain things before any action is performed, other things after any action is performed, prohibiting some actions with prospective rewards, and others with attached punishments, and leaving the remainder to man's free will. Natural jurisprudence is an art teaching the rules through which human reason may perceive the enjoined will of God, and accommodate every part of life to it. Now it must readily be understood, that the matter of natural jurisprudence and ethics differ. Both concern the good, but ethics concerns the good that perfects man and truly brings happiness, whereas natural jurisprudence concerns that good that is just, or rather what is endorsed by the law. We are obliged by the latter good, but not the former. ${ }^{133}$

quella di Samuel Puffendorfio. Non tardò molto avere quanto Volfio, Boeclero, Eineccio ed altri oltramontani avevano fatto qualche cosa rimarchevole sopra cotal materia ... Ma egli non contento di tutto ciò pensò un nuovo Sistema di etica, la cui idea scrisse e fece passare sotto gl'occhi d'alquanti amici."

${ }^{130}$ Antonio Genovesi, Autobiografia, lettere e altri scritti, ed. Gennaro Savarese (Milan, 1962), 18-19: "Che non avevano [sc. i maestri d'etica] quelle cognizioni e quella eloquenza che questa professione ricerca. Per la qual cosa io formai un nuovo piano d'etica."

${ }^{131}$ The chair was not a separate creation-a separate chair was only created in 1777-but a curricular addition to the course offered by the "morning" or mattutina professor of civil law, rewarded with an annual gratuity of 100 ducati. Cammisa, L'Università, 304, 331.

${ }^{132}$ For Cirillo's criticism of Genovesi see Giuseppe Maria Galanti, Memorie storiche del mio tempo e altri scritti di natura autobiografica, 1761-1806, ed. Augusto Placanica (Cava De' Tirreni, 1996), 61.

${ }^{133}$ Giuseppe Pasquale Cirillo, "Juris naturalis ac gentium: Prolegomena," in Cirillo, Opera omnia, 2 vols. (Naples, 1781-3), 2: 270-319, at 277: "Ecce nunc tibi absolutissimam juris naturalis definitionem. Naturale jus est voluntas Dei per rectam rationem humano generi promulgata, quaedam nullo praeeunte hominis facto, quaedam posito facto hominis jubens, vetansve propositis praemiis, adjectisque poenis, reliqua omnia libero hominis arbitrio permittens. Ecce etiam tibi definitionem Jurisprudentiae naturalis. Ars est regulas tradens, quibus humana ratio praecipientem Dei voluntatem cognoscat, accommodatque ad omnem vitae partem. Jam vero facile intellectu est, qua re naturalis Jurisprudentia, atque Ethica differant inter se. Utraque circa bonum versatur; sed haec bonum spectat, qua hominem perficit, ac vere felicem reddit: illa bonum, qua justum est, seu qua Lege sancitum est: proinde ad posterius hoc bonum obligamur: non item ad prius illud." 
As Genovesi explained in his first Autobiografia, his "system" would commence with a study of the "physiology of man," or our "inclinations, passions, virtues and vices" (Book 1), before demonstrating the existence of God and the law of nature, and our "need of a regulatory law to live well" (Book 2). Book 3 would survey "the principal systems of great men who have discussed the law of nature" and Book 4 would conclude with "the various duties of men."134 In other words, the four books would intermix "ethics" with "natural jurisprudence," in Cirillo's terms.

One possibility is that Cirillo admired Genovesi's sistema because it then consisted only of Book 1, or a self-standing tractate in which Genovesi might have described the "virtues" as supererogatory. Portions of Book 1 were discussed in chapters of Genovesi's Psychesophia (1747), but the excursus concluded abruptly with a note that Genovesi would "not proceed further; since, if life permits, I intend to complete this discussion more copiously in my Ethica."135 This work, Genovesi's "Ethica" or "Elementa ethicae," never appeared in print, but its constituent parts survive in the Psychesophia (Book 1) and De legibus naturae (Books 2-4). ${ }^{136}$ In 1765, Genovesi reworked the latter into De jure et officiis in usum tironum, which he subsequently reissued in Italian as the Diceosina, o sia, della filosofia del giusto e dell'onesto (1766-71). These textbooks differed in several ways from De legibus naturae and reflected the laxer censorial regime of the 1760s, when curial oversight of the book trade was undermined by Bernardo Tanucci, the de facto first minister during the regency of Ferdinando IV (1759-67). ${ }^{137}$ De legibus naturae was nonetheless a radical departure from the form of "ethics" propounded by de Loya and Amati, or any surviving prelection in the subject in Italy en bloc. This is what inspired Genovesi's colleague-and arch-critic-Giacomo Martorelli to protest that "Genovesi believes himself to be a Grotius, or a Wolff." ${ }^{138}$ Martorelli's was one of several complaints about Genovesi's orthodoxy after 1743, and it culminated in an investigation by the Index between 1753 and 1758, when a litany of statements in the Ontosophia, Psycheshophia and Elementorum artis-logico criticae (1745) were censured. ${ }^{139}$ Protected by Tanucci, Genovesi confidently persisted in republishing his works without emendation, and brazenly claimed to have the imprimatur of Benedict XIV, after he shrewdly addressed an epistle dedicatory to the latter in the Psychesophia. Benedict's brisk and laudatory response was published with the

\footnotetext{
${ }^{134}$ Genovesi, Autobiografia, 18-19.

${ }^{135}$ Genovesi, Elementa metaphysicae: Psychesophia (Naples, 1747), 259: "Capita attigi virtutem humanarum. Ea qui probe servabit grandem proculdubio gradum in vita recte gubernanda fecit. Rem autem ulterius non proveho, copiosus id in Ethica, si vita suppetat, facturus."

${ }^{136}$ For additional references to the Elementa ethicae see Antonio Genovesi, Elementa metaphysicae: Ontosophia (Naples, 1743), 28-9; Genovesi, Elementorum artis logico-criticae (Naples, 1745), 61-2; Genovesi, Elementa metaphysicae: De legibus naturae (Naples, 1752), sig. c3v.

${ }^{137}$ For this process see Maria Grazia Maiorini, "Bernardo Tanucci e il Catechismo del Mésenguy," Storia e Politica 16 (1977), 610-63.

${ }^{138}$ Parma, Biblioteca Palatina, cass. 83, n. 563, Giacomo Martorelli to Paolo Maria Paciaudi [c.1762]: "credo che sapete, che Genovese per la ristampa si diabolicamente accresciuta della sua metafisica ... ed egli crede d'essere un Grozio, o un Wolfio."

${ }^{139}$ For this censure see Nicola Borchi, "I guai di un apologista newtoniano: la Metaphysica e l'Ars logicocritica di Genovesi processati dalla Congregazione dell'Indice," Giornale Critico della Filosofia Italiana 20 (2000), 386-400; Borchi, "Quando l'inquisitore si distrae: ancora sul processo alla Metaphysica e all'Ars logico-critica di Genovesi,” Giornale Critico della Filosofia Italiana 22 (2002), 405-29.
} 
volume in 1747 , inspiring Genovesi to issue every subsequent instalment of the Elementa metaphysicae, including De legibus naturae, with a dedication to the pontiff. ${ }^{140}$ Benedict subsequently oversaw the retention of Grotius, Pufendorf and Heinecke on the Index in 1758, when reformist voices in the curia were pressing the Congregation to permit the republication and sale of their works. ${ }^{141}$ The request arose, in part, from the unceasing circulation of "modern natural law" in the peninsula's libraries and universities. In 1746, Heinecke's Praelectiones on De iure belli ac pacis and De officio hominis et civis was published in two volumes in Venice, with a false imprint. ${ }^{142}$ In 1757-9, Giuseppe Almici produced the first Italian translation of Pufendorf's De jure naturae et gentium, published in four volumes in Venice, "con licenza de' superiori." "143

Genovesi's role in spurring this change is difficult to understate. De legibus naturae was repeatedly republished in Naples $(1756,1763,1774)$, Venice (1753, $1762,1764,1786)$ and Bassano $(1764,1779,1785)$. In a prolusion delivered at Lugano in 1755 by Paolo Frisi, Genovesi-together with Francesco Maria Zanotti of Bologna and Jacopo Stellini of Padua - was credited with teaching "the duties of Man and Citizen," in a manner that "would have otherwise remained with the oltremontani." 144 However, it is important to reemphasize that Genovesi was merely developing an intellectual trend that Galiani had cultivated in the 1720 s. The difference was the extent to which Genovesi was prepared systematically to describe the systems of Grotius, Pufendorf and others in a published textbook, recalling that Galiani's Ricerche had remained "solo per mio uso." In shaping the study of ethics in the University of Naples after $c .1740$, Genovesi succeeded in normalizing the use of Grotius and his followers to address a question, on our natural sociability, that would formerly have fallen within the curricular precincts of moral theology, if it was addressed within the curriculum at all.

De legibus naturae was focused primarily on sociability. In successive chapters, Genovesi discussed how Hobbes, Grotius, Pufendorf, Heinecke and Wolff had resolved the question of our inclination to obey natural law and coexist in civil society. God, Genovesi writes, instills reason in humankind, which gives rise to our recognition of His perfection and omnipotence. ${ }^{145}$ Hobbes and other "Epicureans" are wrong to describe morality as factitious. ${ }^{146}$ We can perceive "the just or the unjust" by nature. But this perception depends on our recognition of the existence of "the most supreme being." " ourselves and secure "pleasure." ${ }^{148}$ But we are not constructed to inflict harm on

\footnotetext{
${ }^{140}$ Gennaro Maria Monti, Per la storia dei Borboni di Napoli e dei patrioti meridionali (Trani, 1939), 349-62.

${ }^{141}$ Patrizia Delpiano, Il governo della lettura: Chiesa e libri nell'Italia del Settecento (Bologna, 2007), 90-91.

${ }^{142}$ Patrizia Bravetti and Orfea Granzotto, eds., False date: repertorio delle licenze di stampa veneziane con falso luogo di edizione (1740-1797) (Florence, 2008), 66.

${ }^{143}$ Diego Panizza, "La traduzione italiana del De jure naturae di Pufendorf: giusnaturalismo moderno e cultura cattolica nel Settecento," Studi Veneziani 11 (1969), 483-528; Maurizio Bazzoli, "Giambattista Almici e la diffusione di Pufendorf nel Settecento italiano," Critica Storica 16 (1979), 3-100.

${ }^{144}$ Paolo Frisi, Saggio della morale filosofia (Lugano, 1755), i.

${ }^{145}$ Genovesi, Elementa metaphysicae: De legibus naturae, sig. a5r.

${ }^{146}$ Ibid., 29.

${ }^{147}$ Ibid., sigs. a4v, b8v.

${ }^{148}$ Ibid., sigs. a4r, a8v.
} 
others. Instead, we are "friendly." ${ }^{149}$ Grotius is correct to describe this as an innate appetitus societatis. ${ }^{150}$ Although our free will allows us to act in violation of God's intentions, we are not morally incapacitated. "Malignity" is a product "of our will, not our nature." 151 "The confusion and corruption of human behaviors-which are used to confute the idea of an appetitus societatis-are of no moment against the system of Grotius," Genovesi insists. The principles of the law of nature cannot be discovered by the "adventitious qualities and vices" of human behavior, but must be found "within our innate and essential properties." 152 These are, as Wolff explains, elements of our "rational nature,"153 and they impel us to observe our two preeminent officia: giving to each his due and refraining from harming others. ${ }^{154}$ Other officia benevolentiae are "obligatory," as they conduce to sociable life. ${ }^{155}$ No man, pace Heinecke, is born into a solitary state of nature. ${ }^{156}$ Instead, we are born into society, and obliged to observe "the most important law, which pertains to all men," namely "the happiness of the human race."157

Genovesi clearly felt that the origins of civil society could be explained in Grotius's terms, admixed with a series of eclectic qualifications about (inter alia) the obligatory character of "benevolence." His conclusions are not unrecognizably distant from the axioms of Thomist moral theology or eudaimonistic ethics, as Genovesi would insist in his responses to clerical critics. This partly explains Frisi's comparison of Genovesi with Zanotti, the author of La filosofia morale secondo l'opinione dei Peripatetici (1754), and the extent to which recent historiography has situated Genovesi's work in a continuum between eudaimonism and felicific theories of sublunary government in Italy, in the genre inaugurated by Ludovico Antonio Muratori's Della pubblica felicità (1749). ${ }^{158}$ But it bears repeating that Aquinas and scholastic commentaries are conspicuous by their absence from De legibus naturae. The tendency was not embraced uniformly by Genovesi's contemporaries. In 1764, Genovesi's prize student Francesco Longano published a Piano di un corpo di filosofia morale which was focused principally on the

\footnotetext{
${ }^{149}$ Ibid., sig. b8v: “omnes comparati simus, ut non modo neminem laedere velimus, sed omnibus et esse velimus, atque simus amici."

${ }^{150}$ Ibid., 59.

${ }^{151}$ Ibid., sig. b2r.

${ }^{152}$ Ibid., 62: "Quae vero adversus adpetitum societatis opponi solent, ex perturbatis, atque corruptis hominum moribus nullius sunt momenti adversus Grotianum systema. Principium enim cognoscitivum legum naturalium, quemadmodum superius observatum est, non est desumendum a qualitatibus, et vitiis naturae humanae adventitiis, sed a proprietatibus insitis, et essentialibus."

${ }^{153}$ Ibid., 98-100.

${ }^{154}$ Ibid., 202.

${ }^{155}$ Ibid., 211: "Obligari autem nos et ad haec officia [sc. benevolentiae], et natura ipsa humana, et conditio societatis demonstrat."

${ }^{156}$ Ibid., 60.

${ }^{157}$ Ibid., sig. c2r: "Quae hinc nascuntur leges, ad omnes pertinent homines, quarum summa est, totius generis humani felicitas."

${ }^{158}$ Antonio Trampus, "Morale, felicità e diritto: metamorfosi di linguaggi tra Genovesi e Verri," in Donatella Balani, Dino Carpanetto, and Marina Roggero, eds., Dall'origine dei Lumi alla Rivoluzione. Scritti in onore di Luciano Guerci e Giuseppe Ricuperati (Rome, 2008), 537-58; Cristina Passetti, "Una fragile armonia: felicità e sapere nel pensiero di Antonio Genovesi," in Anna Maria Rao, ed., Felicità pubblica e felicità privata nel Settecento (Rome, 2012), 287-300.
} 
explication of the "virtues," as Capece recorded in its stilted Greek epigraph. ${ }^{159}$ In 1769, when Capece, a Theatine, was translated to the archbishopric of Trani, concorrenti for his chair were asked to discuss a locus from Aristotle "on the nature of friendship." ${ }^{160}$ But if Genovesi did not forge a clean break with these fixations, he cultivated a significant disjunction, in which Aristotelianism and the writings of the "Second Scholastic" were extruded from the curriculum of a Catholic university.

\section{III}

In 1752, Galiani's friend and confidant Romualdo de Sterlich informed Filippo Argelati, the librarian of the Biblioteca Ambrosiana, that De legibus naturae had appeared in Naples with "applause." ${ }^{161}$ De Sterlich compared Genovesi's work to Nicolò Ghezzi's recent De' principj della filosofia morale (1752)-a Jesuit tract that he dismissed as a defense of "probabilism"-and he arranged for a copy of De legibus naturae to be sent to Milan. ${ }^{162}$ Argelati himself had earlier sent works to de Sterlich via Galiani, who might have dispatched Genovesi's De legibus to Milan on de Sterlich's behalf. ${ }^{163}$ Galiani's response to De legibus is nonetheless unknown, but it is not difficult to believe that the work had fulfilled his aspiration of reforming the curriculum in moral philosophy. In 1746 Giovanni Giuseppe Origlia published De' principi del diritto naturale, a work of remarkable similarity to Genovesi's De legibus, ${ }^{164}$ which appealed enough to Galiani's predilections that he reportedly favored Origlia over Capece in the concorso for the chair of ethics in $1754 .^{165}$ In 1748, Nicola Bammacaro's Tentamen de vi electrica, a treatise on electricity dedicated to Galiani, began rather eccentrically with a vindication of Grotius's "principles of universal law," in a manner that can only suggest Galiani's sympathies were known publicly. ${ }^{166}$

Pace Robertson, it was not the case that Catholic thinkers were "unable to draw on the resources of natural law" in the later seventeenth or early eighteenth

\footnotetext{
${ }^{159}$ Gaetano Maria Capece, "Epigramma ad Ab. Franciscum Longanum," in Francesco Longano, Piano di

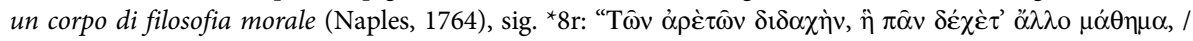

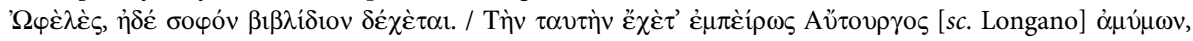

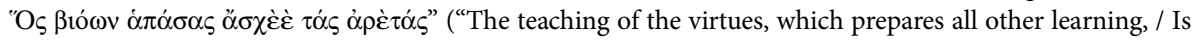
prepared by this useful and wise little book. / The teaching of the virtues the peerless author possesses from experience, / Who in his life exercises all the virtues").

${ }^{160}$ For the use of this locus see Nicola Barone, "Alessio Aurelio Pelliccia cattedratico di diplomatica nella R. Università degli studi di Napoli nel primo quarto del sec. 19," Atti dell'Accademia Pontaniana 35 (1905), 3-24, at 4, 17 n. 8; and Matteo Angelo Galdi, Francesco Mario Pagano, and Francesco Saverio Salfi, Teatrali contese, ed. Alberto Granese (Salerno, 1999), 3.

${ }^{161}$ Milan, Biblioteca Ambrosiana, ms. Trotti, 284, fo. 21v, Romualdo de Sterlich to Filippo Argelati, 30 November 1752.

${ }^{162}$ Ibid., fo. 29r, de Sterlich to Argelati, 29 January 1753: "[Genovesi] convince, a differenza del P. Ghezzi, che con que' suoi dialogoni tira a ristuccare la pazienza d'un novizio cappuccino; e poi cosa conchiude? Che il probabilismo non è quel gran male, che il mondo crede."

${ }^{163} \mathrm{Ibid}$., fo. 31r, de Sterlich to Argelati, 10 May 1753.

${ }^{164}$ Giovanni Giuseppe Origlia Paolino, De’ principj del dritto naturale (Naples, 1746).

${ }^{165}$ Cammisa, L'Università, 74. For Galiani's support of Origlia see Vatican, Biblioteca Apostolica, Vat. lat. 12564, fo. 421r, Niccolò Fraggianni to Domenico Passionei, 4 February 1755.

${ }^{166}$ Nicola Bammacaro, Tentamen de vi electrica (Naples, 1748), ii.
} 
centuries. $^{167}$ This is far from positing that Grotius or his followers were uncomplicatedly enfolded into orthodox Catholicism. Robertson singles out Giovanni Guarini, a Palermitan Jesuit who published a defense of Thomist natural law in $1759,{ }^{168}$ as an example of an Italian Catholic who continued to utilize the language of the "Second Scholastic." Yet Guarini's concern lay as much with the objectionable content of Protestant moral reasoning as it did with the incursion of this reasoning into Catholic countries. Guarini's manuscript Philosophia rationalis (1759), used in Palermo's Jesuit Collegio massimo, attacked the "philosophical system" of Wolff precisely because "his books have come to be thoroughly read everywhere, even in Catholic regions where the system of indifferent liberty," or Molinism, the Jesuits' preferred theology of free will, "flourishes."169

The history of this process requires further investigation, particularly if we are to understand "the general problem of the decline of the Second Scholastic," as Robertson has described it. ${ }^{170}$ A significant component of any history must relate to the use of "civil law" as an alternative mode of moral education. This formed the subject of a considerable debate after the publication of Muratori's De i difetti della giurisprudenza (1742), which elicited a response from Giuseppe Cirillo, among others. $^{171}$ In the same manner, the infiltrations of Jansenist moral theology in Catholic contexts require particular attention: Jansenism could command only a muted following after its proscription by the papal bull Unigenitus in 1713, but its influence in the primo Settecento-or before its resurgence in the second half of the eighteenth century, when it evolved into a hybrid theology of neo-Augustinianism, regalist ecclesiology, and "sober" or unsuperstitious pietyis appreciable. ${ }^{172}$ Gianvincenzo Gravina, a widely admired Calabrian jurist, appointed professor of civil law in the University of Rome in 1699, echoed the Jansenist critique of Jesuit moral theology in his Hydra mystica (1691), and used his Originum juris civilis (1708) - republished at Naples in 1713-to offer a suggestively neo-Augustinian account of humankind's passional motivations, in a section "de origine societatis humanae." 173

Notwithstanding these absences, the argument advanced thus far can clarify a significant aspect of the "decline of the Second Scholastic." In early eighteenth-

\footnotetext{
${ }^{167}$ Robertson, "Sociability," 63.

${ }^{168}$ Ibid., 65 (misidentified as "Giovanni Guarino"), citing Annabel Brett, "The Civil Philosophy of Hugo Grotius," Historical Journal 45/1 (2002), 31-51, at 51 n. 75, which refers to the extract of Guarini's Juris naturae, et gentium principia et officia ad Christianae doctrinae regulam exacta, et explicata a doctore eximio Francisco Suarez S. J. digessit (Palermo, 1759) in J.-P. Migne, Theologiae cursus completus, 28 vols. (Paris, 1839-45), 15: 375-446.

${ }^{169}$ Palermo, Biblioteca Centrale della Regione Siciliana, ms. V C 23, Giovanni Battista Guarini, Philosophia rationalis (1759), p. 137: "Non nego Wolphium loqui paulo lautius ... sive q[uo]d esset, libros suos ubiq[ue] perlegi, etia[m] in Catholicorum regionibus ubi viget systema libertatis indifferentiae."

${ }^{170}$ Robertson, "Sociability," 64.

${ }^{171}$ For a discussion of this development see Manuela Bragagnolo, "Lodovico Antonio Muratori giurista e politico" (unpublished Ph.D. thesis, Università degli Studi di Trento, 2007-8), 133-94.

${ }^{172}$ For a summary of this vast literature see Pietro Stella, "Gli intellettuali a Napoli e la cultura giansenista tra Seicento e primo Settecento," in Stella, Il giansenismo in Italia, 3 vols. (Rome, 2006), 1: 167-97.

${ }^{173}$ Gianvincenzo Gravina, Originum juris civilis libri tres, 2 vols. (Naples, 1713), 1: 215-24; Fabrizio Lomonaco, "Diritto naturale e storia: Note su Gravina e Vico," Archivio di Storia della Cultura, 13 (2000), 27-51.
} 
century Naples, the resources of Grotius and his followers were adopted in lieu of a superannuated curriculum in moral reasoning. The impulsions of this change were various and complex, but any suggestion that it issued in an attachment to "sacred history" is misplaced. Vico's approach was exceptional. Indeed, in a chapter of $D e$ legibis naturae, "de statu hominis sociali," Genovesi included a precis of "the ingenious system of our Vico, who contends that men were impelled from their bestial state into marriage, and thence families, by thunder. Thus, partly by natural law, and partly by fear of nefarious things, cities and civil power were born." ${ }^{174}$ This is the only reference to Vico throughout the work, and the only intimation that Genovesi regarded Scienza nuova as relevant to his purposes. In his manuscript Elementa theologiae (c.1741), Genovesi would expressly criticize Vico on the same point: the manuscript summarizes Scienza nuova's position on sociability, ${ }^{175}$ yet it raises a trenchant objection to Vico's claim that our ancestors, after the Flood, were "bestial" in temperament: "It does not agree sufficiently with Divine Providence to let humans pass into a bestial state."176 Scienza nuova elicited a flurry of discordant responses, some in admiration, some in perplexed disbelief. ${ }^{177}$ Genovesi's response reveals the extent to which the Catholic reception of "modern natural law" can inflect our interpretation of these responses: Genovesi dismissed Vico's account of human sociability in Scienza nuova precisely because he had accepted the alternative propounded by Grotius.

Acknowledgment. For their comments on this article, the author thanks Dr Melissa Calaresu, Dr Robin Mills, Professor John Robertson, and the peer reviewers for Modern Intellectual History.

\footnotetext{
${ }^{174}$ Genovesi, Elementa metaphysicae: De legibus naturae, 238: "Inprimis vero ingeniosum est Vici nostri Sistema, qui ex ferino statu tonitru homines ad nuptias, et hinc familias, impulsos fuisse contendit. Inde vero partim amore naturali, partim nefariorum metu natas Civitates, et Imperia civilia."

${ }^{175}$ Antonio Genovesi, Universae Christianae theologiae elementa, 2 vols. (Venice, 1771), 1: 237.

${ }^{176}$ Macerata, Biblioteca Comunale Mozzi Borgetti, ms. 340, Antonio Genovesi, Universae Christianae theologiae elementa (1763), fo. 161r: "Postremum non satis consentit cum Providentia Divina hominem sinere in hujusmodi statum abire." This passage is absent from the other accessible manuscripts of Genovesi's Elementa theologiae: Bari, Biblioteca Nazionale Sagarriga Visconti-Volpi, ms. III 116; Bari, Biblioteca Provinciale Santa Teresa dei Maschi-De Gemmis, Fondo de Gemmis, f. b., XCV/1; Fano, Biblioteca Comunale Federiciana, ms. 94.

${ }^{177}$ For a systematic overview of Vico's reception see Benedetto Croce and Fausto Nicolini, Bibliografia vichiana, 2 vols. (Naples, 1947-8), 1: 165-313; and the discussion in Felix Waldmann, "Antonio Genovesi, the 'scuola genovesiana', and philosophy in the Kingdom of Naples, 1743-1792" (unpublished Ph.D. thesis, University of Cambridge, 2016), 219-48.
}

Cite this article: Waldmann F (2022). Natural Law and the Chair of Ethics in the University of Naples, 1703-1769. Modern Intellectual History 19, 54-80. https://doi.org/10.1017/S1479244320000360 